\title{
Metal-Induced Chiral Folding of Depsipeptide Dendrimers
}

\author{
Boris Buschhaus, ${ }^{[a]}$ Frank Hampel, ${ }^{[a]}$ Stefan Grimme, ${ }^{[b]}$ and Andreas Hirsch*[a]
}

\begin{abstract}
The synthesis and metal complexation of chiral depsipeptide dendrimers 3 and $\mathbf{7}$ containing an ethylenediaminetetraacetic acid (EDTA) esterderived core is reported. The EDTA ester cavity of these dendrimers selectively complexes $\mathrm{Zn}^{2+}$ and $\mathrm{Cu}^{2+}$ ions leading to diastereoselective folding. To elucidate the coordination motif in the resulting "foldamers" of $\mathbf{3}-\mathbf{Z n C l}_{\mathbf{2}}$, $\mathbf{7 -} \mathbf{Z n C l}_{\mathbf{2}}, \mathbf{3}-\mathbf{C u C l}_{\mathbf{2}}$, and $\mathbf{7 -} \mathbf{C u C l}_{\mathbf{2}}$, the coordination behavior of the tetramethyl ester of EDTA (8) has been investigated as a model case. The corresponding

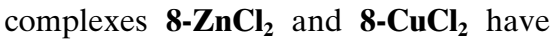
been structurally characterized by ${ }^{1} \mathrm{H}$ NMR spectroscopy and X-ray analysis.
\end{abstract}

The complexes involve the inherently chiral octahedral cis- $\alpha$ coordination motif, in which $\mathbf{8}$ serves as a tetradentate ligand. In the case of the $\mathrm{Zn}^{\mathrm{II}}$ complex $\mathbf{8 - Z \mathbf { n C l }}$, both $\Delta c i s-\alpha(S, S, \lambda)$ and $\Lambda c i s-\alpha(R, R, \lambda) \quad$ stereoisomers were found in the unit cell. For the $\mathrm{Cu}^{\mathrm{II}}$ complex 8- $\mathbf{C u C l}_{2}$, only one stereoisomer, namely $\Delta c i s-\alpha(S, S, \lambda)$ was found in the crystal under investigation. ${ }^{1} \mathrm{H}$ NMR spectroscopy has shown that the

Keywords: chirality $\cdot$ dendrimers · depsipeptides $\cdot$ diastereoselectivity metal complexation $\cdot$ metal-induced folding same coordination motif is diastereoselectively formed in the chiral $\mathrm{Zn}^{2+}$ den-

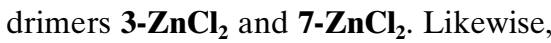
the calculated $\mathrm{CD}$ spectrum of the $\Delta c i s-\alpha(S, S, \lambda)$ stereoisomer of the model complex 8-CuCl $\mathbf{C u}_{2}$ shows good agreement with the experimental spectrum of the $\mathrm{Cu}^{\mathrm{II}}$ dendrimers $\mathbf{3}-\mathbf{C u C l}_{2}$ and $\mathbf{7}$ $\mathbf{C u C l}_{2}$, allowing assignment of the absolute configurations of the preferred foldamers as $\Lambda$ cis- $\alpha(R, R, \lambda)$ for $\mathbf{3}-\mathbf{C u C l}_{\mathbf{2}}$ and $\Delta c i s-\alpha(S, S, \lambda)$ for $\mathbf{7 - C u C l}$. This work represents the first example of metal-complexation-mediated diastereoselective folding of chiral dendrimers with known absolute configuration.

\section{Introduction}

Biopolymers such as DNA and proteins self-assemble with precision and accuracy. The folding process of proteins, which leads to the native, lowest energy structures of these linear polymers, is encoded by the amino acid sequence. ${ }^{[1]}$ Often, metals play an important role in the folding process (e.g. zinc in "zinc fingers") and assist in forcing peptides and proteins to adopt their native conformations. Only correctly folded proteins are able to fulfil their specific functions, such as chiral recognition, enantioselective catalysis, clathration, and transport of small molecules. ${ }^{[2]}$ Misfolded proteins

[a] Dipl.-Chem. B. Buschhaus, Dr. F. Hampel, Prof. Dr. A. Hirsch Institut für Organische Chemie

Friedrich Alexander Universität Erlangen-Nürnberg

Henkestrasse 42, 91054 Erlangen (Germany)

Fax: (+49) 9131-852-6864

E-mail: hirsch@organik.uni-erlangen.de

[b] Prof. Dr. S. Grimme

Organisches Chemisches Institut

Westfälische Wilhelms Universität Münster

Corrensstrasse 40, 48149 Münster (Germany) can aggregate and cause serious illnesses. ${ }^{[3]}$ In recent years, extensive research has been devoted to the preparation of protein mimetics and the elucidation of protein folding in general. ${ }^{[4]}$ The ultimate goal is the development of artificial molecular architectures that are as efficient as the natural machinery.

Dendrimers $^{[5-11]}$ have been investigated as a promising class of protein mimetics owing to their monodisperse and globular structures. ${ }^{[12,13]}$ However, in contrast to proteins, which consist of folded, linear polypeptide chains, dendrimers are based on a tree-like, branched architecture. In most cases, their structures are quite flexible, leading to the co-existence of a multitude of almost isoenergetic conformers. ${ }^{[14]}$ Computational investigations on self-avoiding, neutral dendrimers commonly suggest the presence of backfolded branches. ${ }^{[14-20]}$ However, attractive secondary interactions in the interior and between the end groups can significantly reduce this backfolding. Parquette et al. have described intramolecularly hydrogen-bonded dendrimers showing a solvent- and temperature-dependent chiral conformational order. ${ }^{[21,22]}$ The stability of the secondary structure was seen to be strongly influenced by the globular compaction of the dendrons. ${ }^{[23]}$ In the absence of specific attractive or repulsive 
secondary interactions in chiral dendrimers, ${ }^{[24-27]}$ conformational order was found to be lacking. ${ }^{[28-42]}$

Recently, we introduced the concept of chiral depsipeptide dendrimers as peptide or protein mimetics. ${ }^{[34,43]}$ This new class of dendrimers closely resembles the structures of natural depsipeptides, which consist of $\alpha$-hydroxy and $\alpha$-amino acids connected by ester and amide linkages. ${ }^{[44]}$ We have demonstrated that the conformation within the dendrons is very sensitive to environmental conditions (solvent and temperature) and that a chiral secondary structure might be stabilized in non-protic solvents such as acetonitrile. ${ }^{[43]}$ However, no specific folding motif could be found. We also showed that chirality transfer from the dendron to the focal functionality takes place. ${ }^{[43]}$

We now report on depsipeptide dendrimers that diastereoselectively fold upon metal complexation in a well-defined manner, leading to a chiral secondary structure in the region of the ethylenediaminetetraacetic acid (EDTA)-derived core. In analogy to what is commonly found in metallo-proteins, the metal ions cause a particular arrangement of the organic backbone. Incorporation of metal ions into dendritic structures per se has been investigated previously in a variety of cases. ${ }^{[45-48]}$ Dendrimers containing metal complexes in the core, in the branches, and at the periphery, as well as dendritic systems using metals as branching centers, have been synthesized. ${ }^{[48]}$ However, there have only been a few reports on metal-complexation-induced conformational changes in dendritic ligands. ${ }^{[4-51]}$ Aida et al. have reported on mechanistic aspects of the formation of dendritic dinuclear iron(III) complexes. ${ }^{[49,50]}$ In their work on iron-sulfur core dendrimers, Gorman et al. ${ }^{[52,53]}$ related core encapsulation to the primary dendrimer structure and conformation. Recently, Vögtle et al. ${ }^{[51]}$ have reported on dendritic ligands containing a cyclam core. The complexation rates for $\mathrm{Zn}^{2+}$ ions proved to be dependent on the generation and conformation of the dendrons. However, to the best of our knowledge, metal-complexation-mediated diastereoselective folding of a chiral dendrimer, leading to a certain configuration, has not hitherto been reported.

\section{Results and Discussion}

Synthesis of the depsipeptide dendrimers: To induce a preferred chiral folding motif in the new type of chiral depsipeptide dendrons that we reported recently, ${ }^{[43]}$ the confor- mational flexibility needs to be reduced. The depsipeptide dendrons are based on natural and non-natural tartaric acid building blocks, which are connected to $\omega$-aminocaproic acid spacers through ester and amide bonds (Scheme 1). We

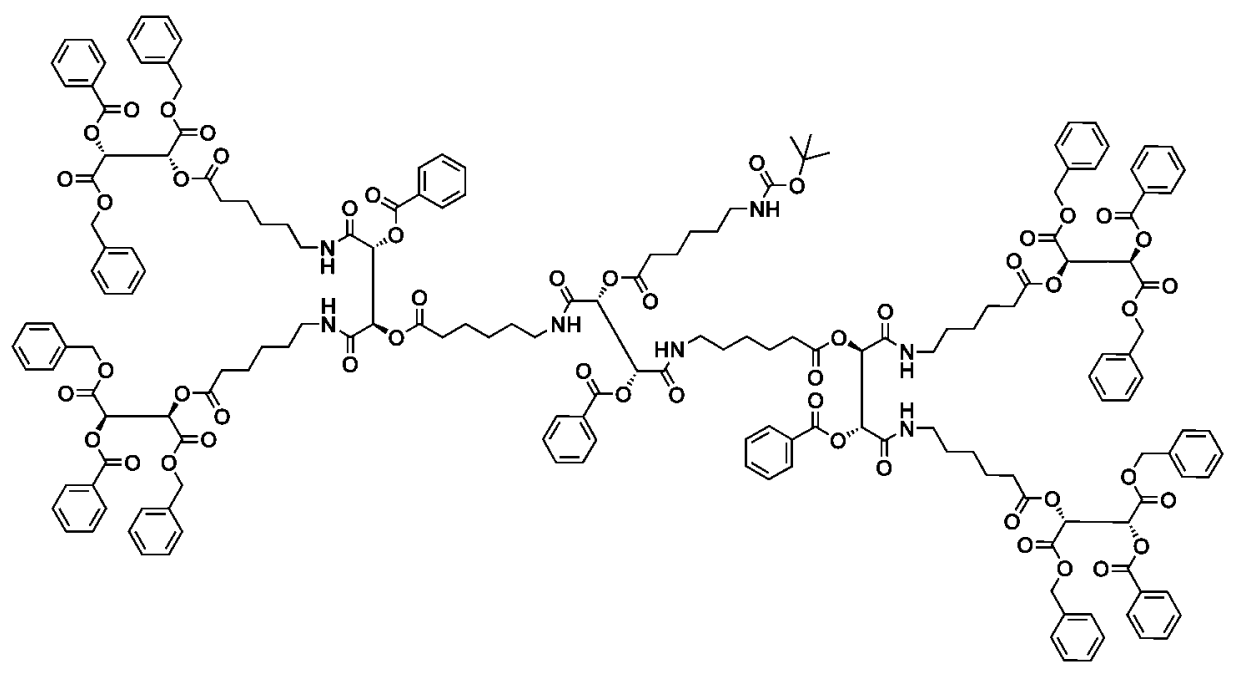

decided to incorporate the tetraester building block derived from ethylenediaminetetraacetic acid (EDTA) $\mathbf{1}$ as a metalchelating dendrimer core. Upon complexation of a metal ion, the entire depsipeptide dendrimer would then be expected to stereoselectively fold in a chiral manner, because a chiral coordination motif can be assumed.

It is surprising that despite the fact that the coordination chemistry of EDTA has been very extensively elaborated, little attention has been paid to its ester derivatives. ${ }^{[54,55]}$ However, copper(II), cobalt(II), and nickel(II) complexes of the tetraethyl ester were prepared by Beyer et al. in the 1960s. ${ }^{[54]}$ The IR spectra of these complexes indicated the presence of bound and "free" ester groups. Although these authors could not determine the structure unambiguously, they suggested that octahedral coordination geometry should be present. Besides the two $\mathrm{N}$ atoms of the EDTA ligand, two coordination sites were expected to be occupied by carbonyl $\mathrm{O}$ atoms of the ester groups, leaving the possibility of the adoption of a chiral coordination geometry. Since in our case enantiomerically pure depsipeptide groups are attached to the EDTA core, the diastereoselective formation of a chiral folding motif around the metal ion could be expected.

The synthesis of EDTA ligand $\mathbf{3}$ incorporating four firstgeneration depsipeptide dendrons is shown in Scheme 2. Reaction of the tris-protected $(R, R)$-tartrate $\mathbf{2}$, which we have recently synthesized, ${ }^{[42]}$ with EDTA 1 proceeded in $55 \%$ yield under slightly modified standard ester coupling conditions. ${ }^{[56,57]}$ For this purpose, we used 1-ethyl-3-(3-dimethylaminopropyl)carbodiimide hydrochloride $(\mathrm{EDC} \cdot \mathrm{HCl})$ in the presence of a catalytic amount of 4-dimethylaminopyridine (DMAP) as the coupling reagent. Long reaction times (ca. 
<smiles>O=C(O)CN(CC(=O)O)CC(=O)O</smiles>

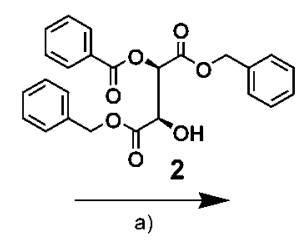
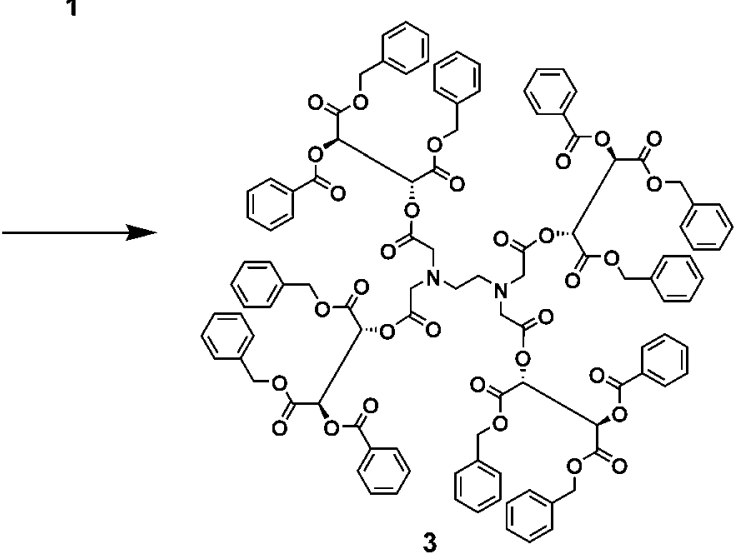

Scheme 2. Synthesis of first-generation $(R, R)_{1}$-dendrimer 3. a) EDC, DMAP, $\mathrm{CH}_{2} \mathrm{Cl}_{2}$, room temperature, 10 days, $55 \%$.

5 days) were found to give the best results, because EDTA is insoluble in all common organic solvents and the reaction therefore proceeds heterogeneously. Considering that four ester bonds are formed, the overall yield is acceptable.

For the synthesis of a related second-generation ligand $\mathbf{7}$ with all- $R$ configuration at the stereogenic centers, we used the depsipeptide dendron $\mathbf{6}$, a structural modification of our previously published systems. ${ }^{[43]}$ In $\mathbf{6}$, the focal functionality is a hydroxy group instead of a protected amine functionality (Scheme 3 ), because it turned out that comparatively long reaction times are required and the hydroxy-terminated dendron proved to be more stable towards decomposition than the corresponding second-generation analogue of $\mathbf{5}$. Moreover, the stereogenic centers in $\mathbf{7}$ are in closer proxim- ity to the central EDTA core, which should lead to more stereoselective formation of chiral metal complexes. The first step in the synthetic sequence leading to 7 was the removal of the benzyl protecting groups of the carboxylic groups of $(R, R)-2$ by stirring with $10 \% \mathrm{Pd} / \mathrm{C}$ in $\mathrm{MeOH}$ under an $\mathrm{H}_{2}$ atmosphere for $24 \mathrm{~h}$. After filtration of the catalyst and evaporation of the solvent, $\mathbf{4}$ was obtained in $99 \%$ yield. Next, the diacid was allowed to react with the deprotected first-generation dendron $\mathbf{5}^{[43]}$ under standard peptidecoupling conditions (DCC, HOBt, $0{ }^{\circ} \mathrm{C}$ ).$^{[58]}$ After purification by flash chromatography, the second-generation dendron 6 was obtained in $54 \%$ yield. Finally, dendrimer 7 (Scheme 4) was assembled by reaction of $\mathbf{6}$ with EDTA 1 (EDC.HCl, DMAP, 5 days). The yield of this fourfold coupling product (18\%) was lower compared to that of $\mathbf{3}$.

For comparison purposes, we also synthesized tetramethyl ethylenediaminetetraacetate $\left(\operatorname{EDTA}(\mathrm{OMe})_{4}\right)(\mathbf{8})^{[59]}$ to serve as a model compound for the metal-binding cavity in the dendrimers 3 and $\mathbf{7}$.<smiles>COC(=O)CN(CCN(CC(=O)OC)CC(=O)OC)CC(=O)OC</smiles>

Metal ion complexation of the dendrimers: Stable metal complexes were formed upon stirring of dendrimers $\mathbf{3}$ and $\mathbf{7}$ in $\mathrm{CHCl}_{3}$ at room temperature in the presence of a large excess $(6 \times)$ of $\mathrm{Zn}(\mathrm{OTf})_{2}, \mathrm{ZnCl}_{2}$ or $\mathrm{CuCl}_{2}$. In the case of the $\mathrm{Zn}^{\text {II }}$ complexes, the ${ }^{1} \mathrm{H}$ NMR spectra provided direct evidence of a successful complexation due to the appearance of a new set of signals (see below). The coordination of $\mathrm{CuCl}_{2}$ was monitored by reversed-phase TLC and by UV spectroscopy.

The $\mathrm{Zn}^{\mathrm{II}}$ dendrimers $\mathbf{3}-\mathbf{Z n C l}_{\mathbf{2}}$ and $\mathbf{7}-\mathbf{Z n C l}_{\mathbf{2}}$ were isolated as colorless solids, whereas the $\mathrm{Cu}^{\mathrm{II}}$ dendrimers $\mathbf{3}-\mathbf{C u C l}_{2}$ and 7- $\mathbf{C u C l}_{2}$ were obtained as light green solids. All these metallodendrimers were found to be very soluble in apolar and polar aprotic solvents such as $\mathrm{CH}_{2} \mathrm{Cl}_{2}$, $\mathrm{CHCl}_{3}$, and $\mathrm{CH}_{3} \mathrm{CN}$, and soluble to some extent in polar protic solvents such as $\mathrm{CH}_{3} \mathrm{OH}$ and EtOH. The complexes were characterized by ${ }^{1} \mathrm{H}$ $\mathrm{NMR},{ }^{13} \mathrm{C} \mathrm{NMR}$, and UV/Vis spectroscopies, mass spectrometry, elemental analysis, and their specific and molar optical rotations $[\alpha]_{\mathrm{D}}$ and $[\varphi]_{\mathrm{D}}$, as well as by $\mathrm{CD}$ spectroscopy. FAB mass spectrometry confirmed the expected molecular weights
Scheme 3. Synthesis of second-generation $(R, R)_{1}-(R, R)_{2}$-dendron 6. a) $10 \% \mathrm{Pd} / \mathrm{C}, \mathrm{CH}_{3} \mathrm{OH}$, room temperature, $24 \mathrm{~h}, 99 \%$; b) DCC, HOBt, $\mathrm{NEt}_{3}, \mathrm{CH}_{2} \mathrm{Cl}_{2}$, room temperature, $24 \mathrm{~h}, 54 \%$. 

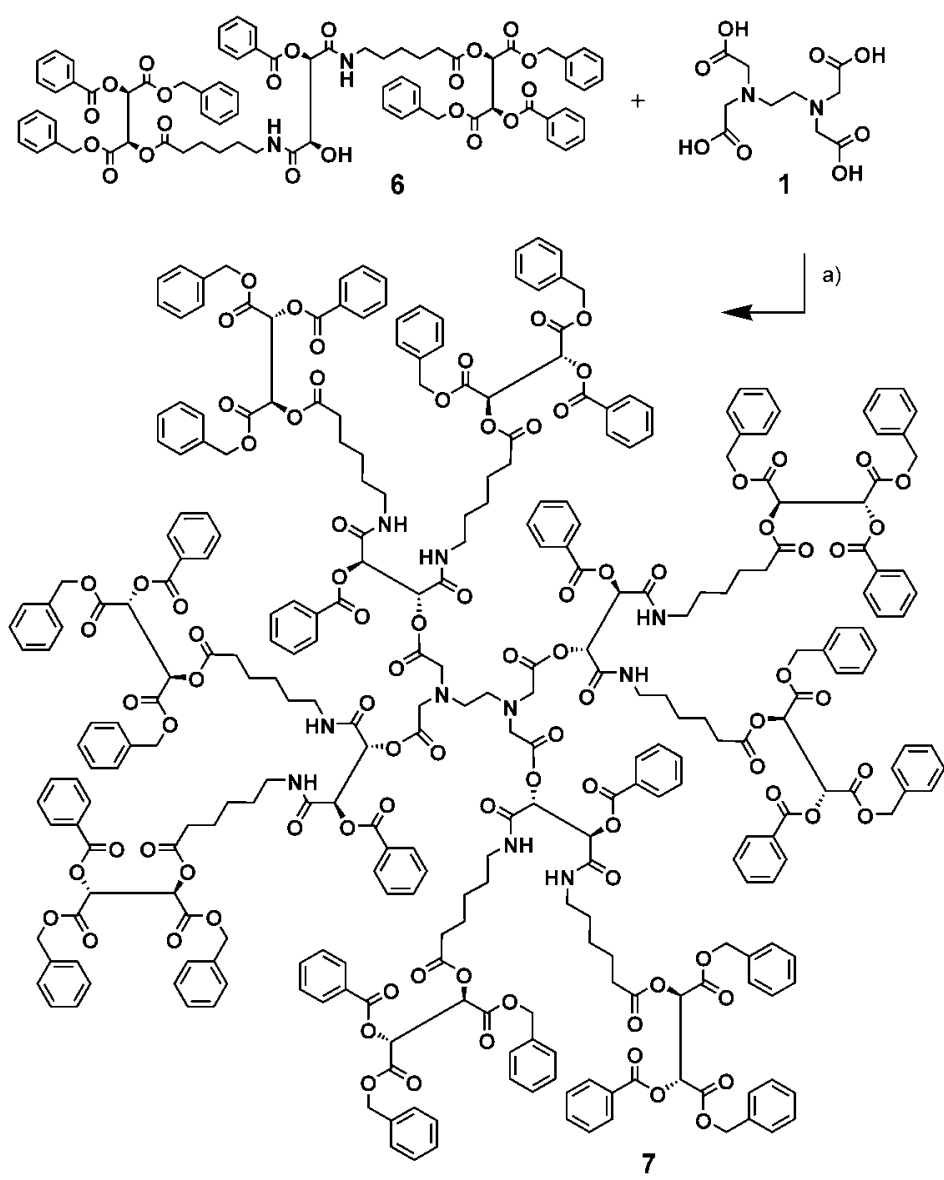

Scheme 4. Synthesis of second-generation $(R, R)_{1}-(R, R)_{2}$-dendrimer 7 . a) EDC, DMAP, $\mathrm{CH}_{2} \mathrm{Cl}_{2}$, room temperature, 10 days, $18 \%$.

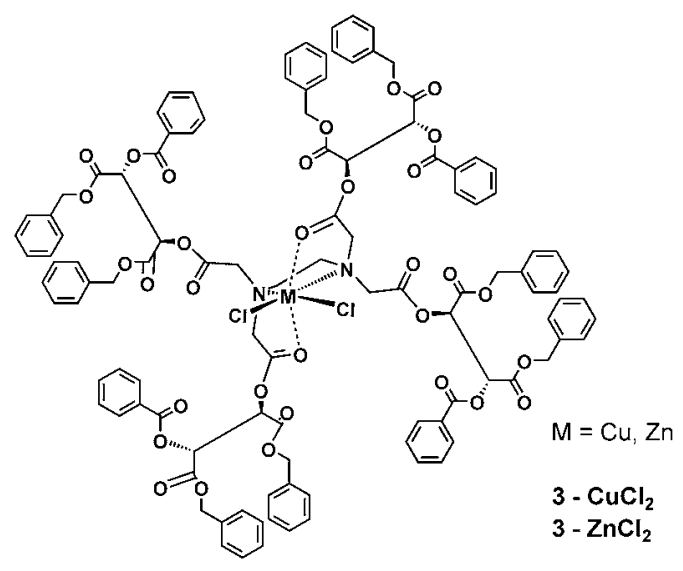

and together with the elemental analyses revealed the purity of the samples.

All attempts to coordinate other metal salts, such as $\mathrm{FeCl}_{2}, \mathrm{FeCl}_{3}, \mathrm{RuCl}_{3} \cdot x \mathrm{H}_{2} \mathrm{O}, \mathrm{CoCl}_{3}, \mathrm{NiCl}_{2}, \mathrm{Na}_{2} \mathrm{PdCl}_{4}, \mathrm{~K}_{2} \mathrm{PtCl}_{4}$, and $\mathrm{Gd}(\mathrm{acac})_{3} \cdot x \mathrm{H}_{2} \mathrm{O}$, proved unsuccessful. Even after a prolonged reaction time and under more forcing conditions (reflux), the ${ }^{1} \mathrm{H}$ NMR, mass, and UV/Vis spectra did not show any indication of metal complexation. This suggests

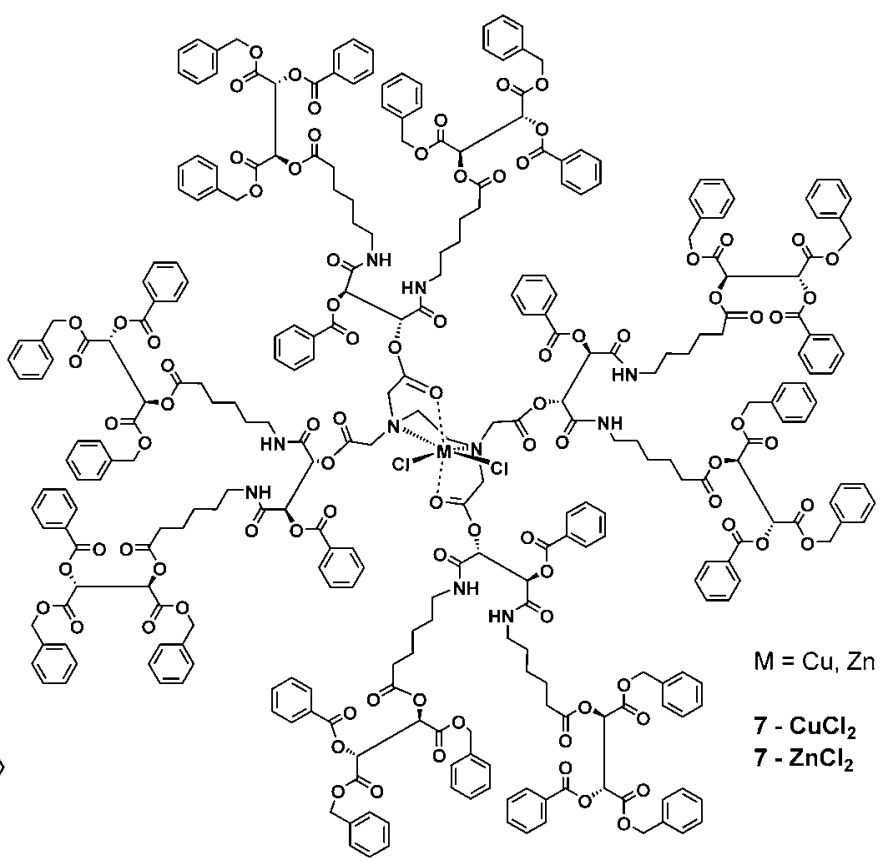

that the metal-binding cavity in the dendrimers $\mathbf{3}$ and $\mathbf{7}$ is quite specific for $\mathrm{Zn}^{2+}$ and $\mathrm{Cu}^{2+}$ ions.

Coordination motif of the model complexes: Important information concerning the coordination motif in these chiral dendritic metal complexes was obtained from X-ray structure analyses of model compounds $\mathbf{8}-\mathbf{Z n C l}_{\mathbf{2}}$ and $\mathbf{8}-\mathbf{C u C l}_{\mathbf{2}}$ (Figure 1, Figure 2). Although Beyer et al. described the copper(II) complex in the 1960s and put forward a proposal for its structure, no X-ray structure analysis of such complexes has hitherto been reported. ${ }^{[54]}$ Hence, we present here the unambiguous structural characterization of such simple EDTA ester-based complexes. The complexes 8-

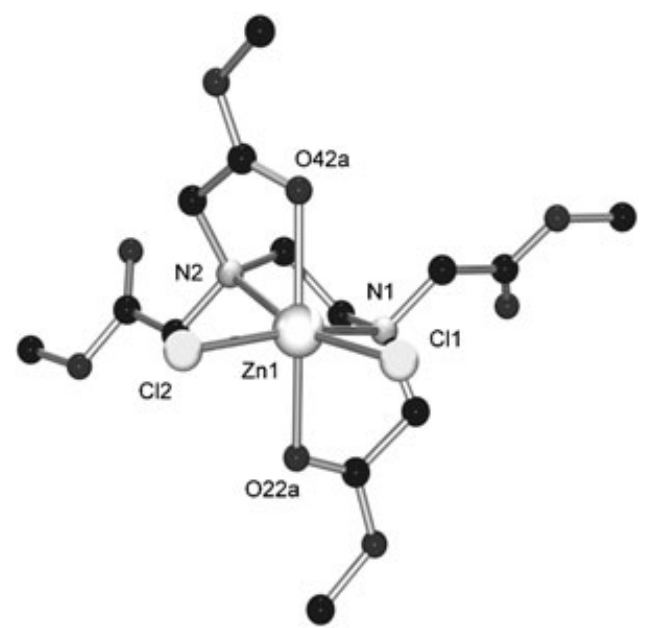

Figure 1. Structure of the $\mathrm{Zn}^{\mathrm{II}}$ model complex $\left(\mathbf{8}-\mathbf{Z n C l}_{2} ; \mathrm{H}\right.$ atoms omitted for clarity). Selected bond lengths $[\AA]$ and angles $\left[{ }^{\circ}\right]: \mathrm{Zn} 1-\mathrm{N} 12.29, \mathrm{Zn} 1-$ O22 a 2.26, Zn1-Cl1 2.30; N1-Zn1-N2 78, Cl1-Zn1-Cl2 102, O42 a-Zn1O22 a 167. 


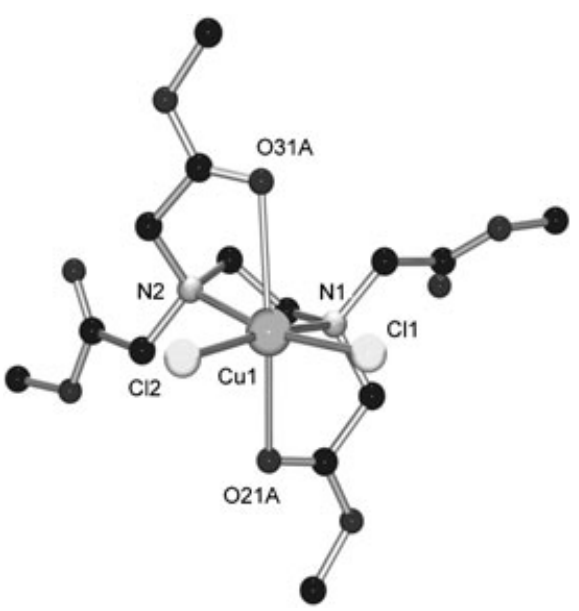

Figure 2. Structure of the $\mathrm{Cu}^{\text {II }}$ model complex $\left(\mathbf{8}-\mathbf{C u C l}_{2} ; \mathrm{H}\right.$ atoms omitted for clarity). Selected bond lengths $[\AA]$ and angles $\left[^{\circ}\right]$ : $\mathrm{Cu} 1-\mathrm{N} 12.10, \mathrm{Cu} 1-$ O21 a 2.50, Cu1-Cl1 2.25; N1-Cu1-N2 83, Cl1-Cu1-Cl2 94, O31 A-Cu1O21 A 161.

$\mathbf{Z n C l}_{\mathbf{2}}$ and 8- $\mathbf{C u C l}_{\mathbf{2}}$ both feature a slightly distorted octahedral geometry about the respective metal centers. The chloride ions are cis coordinated within the equatorial plane. The other two coordination sites of the plane are occupied by the amino $\mathrm{N}$-atoms of $\mathbf{8}$. The axial positions are occupied by the carbonyl $\mathrm{O}$-atoms of the ester.

In principle, linear tetradentate ligands can occupy four consecutive positions of an octahedral complex in three different ways, namely cis- $\alpha$, cis- $\beta$, and trans $^{[60]}$ (Figure 3 ). The

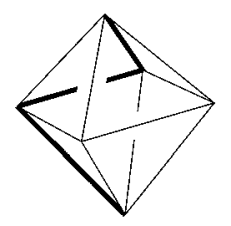

$\Lambda \operatorname{cis}-\alpha$

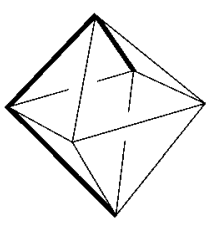

$\Lambda \operatorname{cis}-\beta$

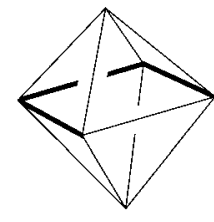

trans
Figure 3. Schematic representation of all possible edge configurations in octahedral complexes involving tetradentate ligands.

cis- $\alpha$ and cis- $\beta$ configurations are chiral and exist in enantiomeric $\Delta$ and $\Lambda$ forms. Furthermore, the atoms of the ethylenediamine chelate ring backbone can exist in two dissymmetric skew-boat conformations, denoted as $\delta$ and $\lambda$ (Figure 4). ${ }^{[61]}$ The five-membered ring is twisted or puckered

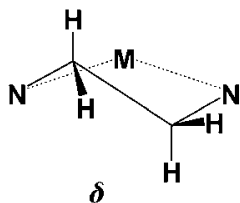

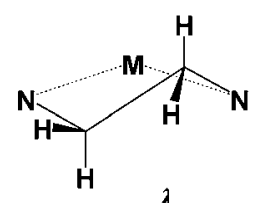

$\lambda$
Figure 4. Schematic representation of $\delta$ and $\lambda$ gauche conformations of the ethylenediamine ligand backbone. so that the hydrogen atoms on adjacent atoms are in a staggered or gauche conformation. ${ }^{[62]}$ Lattice effects in the crystals force the ethylenediamine ligand to adopt its more stable conformation, but it is known that the $\delta-\lambda$ inversion has an activation barrier of only about $0.6 \mathrm{kcal} \mathrm{mol}^{-1}$ and that the ethylenediamine ligands therefore undergo rapid inversion in solution. ${ }^{[61]}$ After coordination to the central metal ion, the two $\mathrm{N}$-atoms of the ligands become stereogenic centers $(S, S-, R, R$ - or $R, S$-configuration, depending on the overall $\Delta$ and $\Lambda$ configuration), irrespective of which coordination motif, $c i s-\alpha, c i s-\beta$ or trans, is adopted. Altogether, twenty stereoisomers, $\Delta c i s-\alpha(S, S, \delta), \Delta c i s-\alpha(S, S, \lambda), \Lambda c i s-\alpha-$ $(R, R, \delta), \Lambda c i s-\alpha(R, R, \lambda), \Delta c i s-\beta(R, S, \lambda), \Delta c i s-\beta(R, S, \delta), \Delta c i s-\beta-$ $(R, R, \lambda), \Delta c i s-\beta(R, R, \delta), \Lambda c i s-\beta(S, R, \lambda), \Lambda c i s-\beta(S, R, \delta), \Lambda c i s-\beta-$ $(S, S, \lambda), \Lambda$ cis- $\beta(S, S, \delta), \operatorname{trans}(R, R, \delta), \operatorname{trans}(S, S, \delta), \operatorname{trans}(R, S, \delta)$, $\operatorname{trans}(S, R, \delta)$, trans $(R, R, \lambda), \quad \operatorname{trans}(S, S, \lambda), \operatorname{trans}(R, S, \lambda), \quad$ and $\operatorname{trans}(S, R, \lambda)$ are conceivable for all possible tetradentate complexations of $\mathbf{8}$.

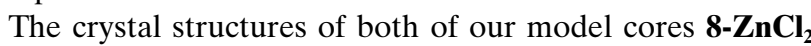
and $\mathbf{8}-\mathbf{C u C l}_{2}$ show that they exclusively adopt the cis- $\alpha$ configuration. Due to the achiral ligand, in each case racemic cis- $\alpha$ species $(\Lambda c i s-\alpha$ and $\Delta c i s-\alpha)$ are formed. In the case of

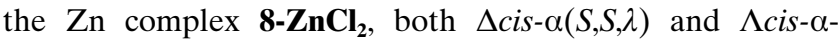
$(R, R, \lambda)$ forms are found in the unit cell. The $\mathrm{Cu}^{\mathrm{II}}$ complex 8$\mathbf{C u C l}_{2}$ crystallizes in its enantiomeric $\Delta c i s-\alpha(S, S, \lambda)$ or $\Lambda$ cis$\alpha(R, R, \lambda)$ form. In the crystal under investigation, the $\Delta c i s-\alpha-$ $(S, S, \lambda)$ configuration was adopted.

The structure of the paramagnetic $\mathrm{Cu}^{\mathrm{II}}$ complex $\mathbf{8}-\mathbf{C u C l}_{\mathbf{2}}$ in solution is difficult to probe by NMR spectroscopy. However, the diamagnetic $\mathrm{Zn}^{\mathrm{II}}$ complex $\mathbf{8}-\mathbf{Z n C l}_{\mathbf{2}}$ allows the application of NMR spectroscopy to compare the solution and

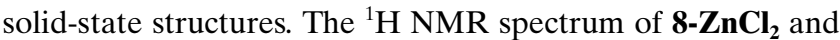
the assignment of the proton resonances are depicted in Figure 5. Upon lowering the temperature, the line width of the signals increases significantly. At $-20^{\circ} \mathrm{C}$, the $\mathrm{N}-\mathrm{CH}_{2}$ signals $1,1^{\prime}$ of $\mathbf{8}-\mathbf{Z n C l}_{2}$ are lost in the baseline. At $-40^{\circ} \mathrm{C}$, two broad signals for the $1,1^{\prime}$ protons appear at $\delta=2.4$ and $\delta=$ $3.1 \mathrm{ppm}$. This behavior can be rationalized in terms of the interconversion of the $\Delta c i s-\alpha$ and $\Lambda c i s-\alpha$ forms (Scheme 5). This process involves breaking of the weak axial oxygenmetal bonds and reformation of the cis- $\alpha$ coordination motif with the opposite configuration. In contrast to this dynamic process, the interconversion between the $\lambda$ and $\delta$ forms $\left(0.6 \mathrm{kcal} \mathrm{mol}^{-1}\right)$ is very fast and cannot be detected by NMR spectroscopy at the temperatures under investigation. Another sensitive probe to distinguish between the coordinating $\left(\mathrm{A}^{\prime}\right)$ and non-coordinating branches (A) (Figure 5) is provided by the diastereotopic methylene protons $2,2^{\prime}$ and the magnetically non-equivalent methyl groups $3,3^{\prime}$. In a frozen geometry, two sets of signals can be expected in each case. The splitting of the signal due to the methylene protons $2,2^{\prime}$ at $-20^{\circ} \mathrm{C}$ and of that due to the methyl protons $3,3^{\prime}$ at $-40^{\circ} \mathrm{C}$ is in accordance with this assumption.

At lower temperatures, the ${ }^{1} \mathrm{H}$ NMR spectra of $\mathbf{8 -} \mathbf{Z n C l}_{2}$ are generally in good agreement with the $C_{2}$-symmetric cis$\alpha$ configuration determined by $\mathrm{X}$-ray crystallography for the solid-state structure. The presence of the $c i s-\beta$ configuration 


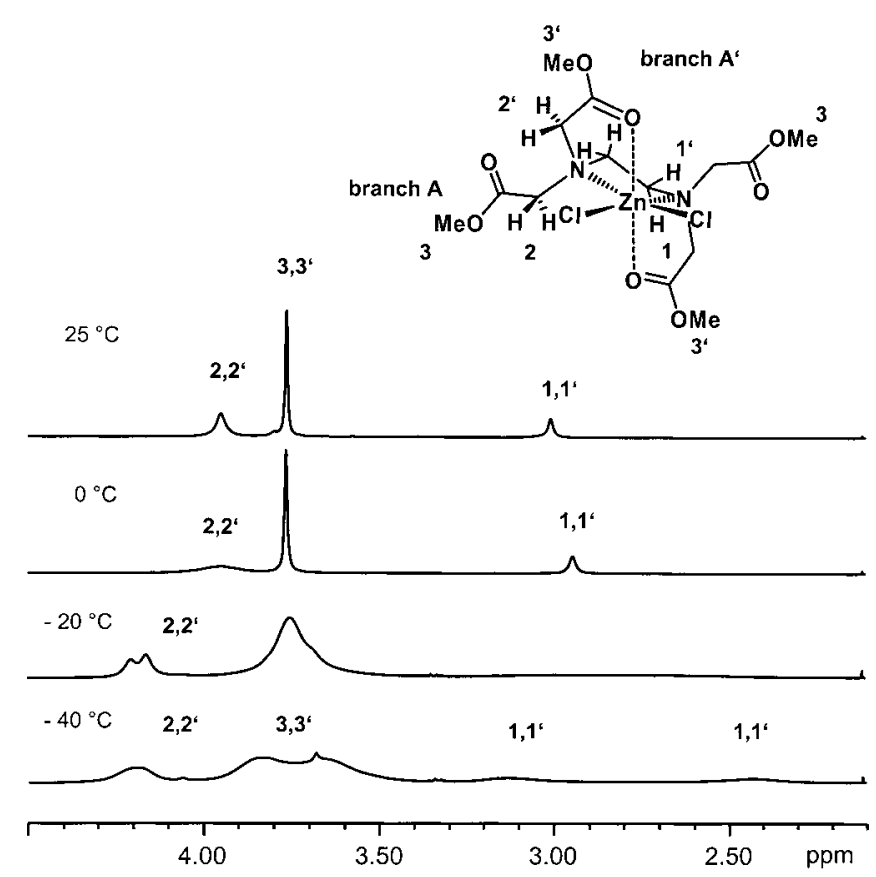

Figure 5. ${ }^{1} \mathrm{H}$ NMR spectra of the model complex $\mathbf{8 -} \mathbf{Z n C l}_{2}$ in $\mathrm{CDCl}_{3}$ at various temperatures.

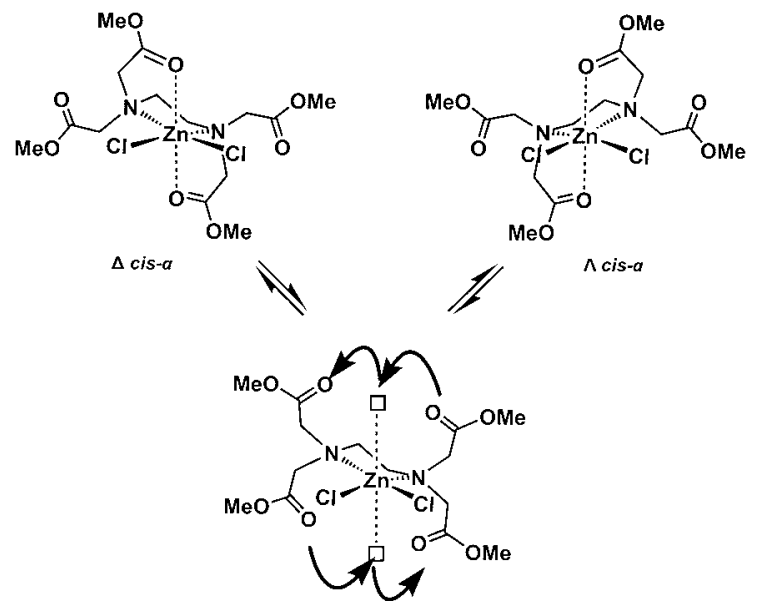

Scheme $5 . \Delta-\lambda$ inversion of $c i s-\alpha-8-\mathbf{Z n C l}_{2}$.

in solution can be ruled out because such complexes involve $C_{1}$-symmetry, which is inconsistent with the simple NMR spectrum. The adoption of an achiral trans configuration in solution, on the other hand, would require an energetically very demanding cis-trans isomerization of the coordinating chloride ions and therefore can also be ruled out.

Coordination motif of the dendrimers: It is reasonable to

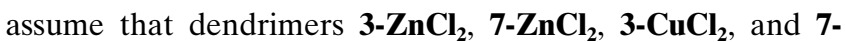
$\mathbf{C u C l}_{\mathbf{2}}$ prefer the same cis- $\alpha$-coordination motif as the model complexes $\mathbf{8 -} \mathbf{Z n C l}_{\mathbf{2}}$ and $\mathbf{8 -} \mathbf{C u C l}_{\mathbf{2}}$. However, the mobility of the coordinating branches is more restricted by steric constraints. Even more importantly, the chiral nature of the enantiomerically pure dendrons should lead to preferential formation of either the $\Delta c i s-\alpha(S, S)\left(\right.$ all- $\left.R_{\text {dend }}\right)$ or $\Lambda c i s-\alpha-$ $(R, R)\left(\right.$ all- $\left.R_{\text {dend }}\right)$ diastereomers.

In the ${ }^{1} \mathrm{H} \mathrm{NMR}$ spectra of the metal-free first-generation dendrimer $\mathbf{3}$, the $C_{2}$-symmetry of the dendritic ligand is reflected by the expected splitting of the signal of the diastereotopic protons into two doublets (Figure 6). In the secondgeneration dendrimer $\mathbf{7}$, the corresponding resonances remain essentially the same.

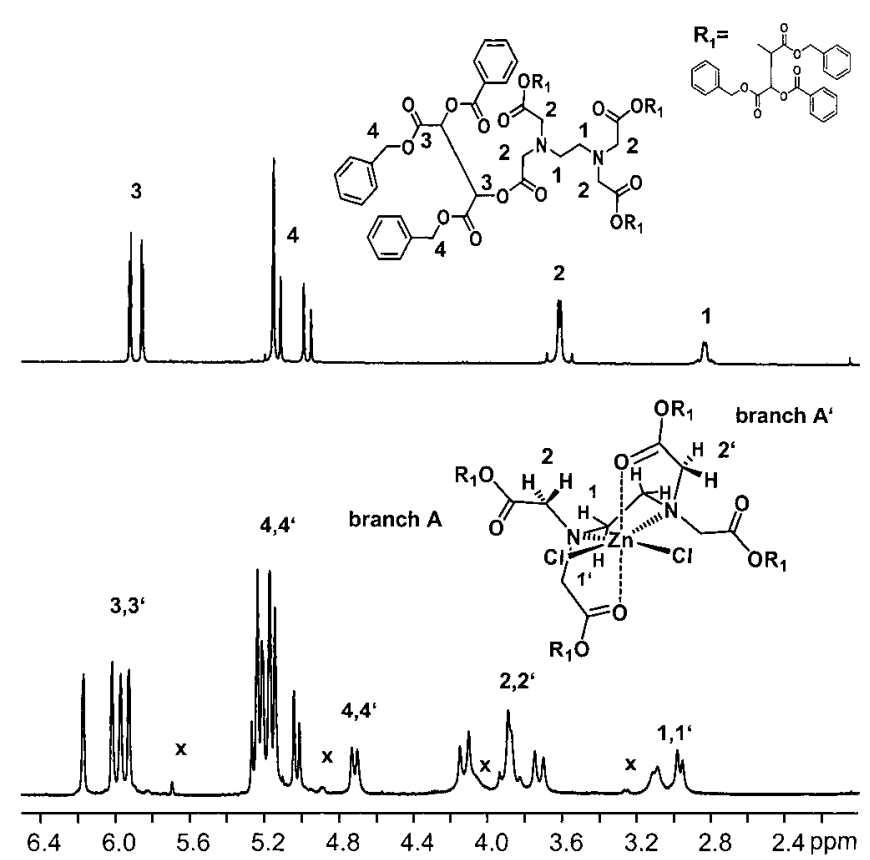

Figure 6. ${ }^{1} \mathrm{H}$ NMR spectra (6.4-2.4 ppm region) of dendrimer 3 and its zinc complex $\mathbf{3}-\mathbf{Z n C l}_{2}$ in $\mathrm{CDCl}_{3}$. Signals indicated with ' $\mathrm{X}$ ' are due to impurities.

The ${ }^{1} \mathrm{H}$ NMR spectra of the diamagnetic $\mathrm{Zn}^{\mathrm{II}}$ dendrimers provide direct evidence for the successful complexation at the EDTA ester-derived core through the appearance of a new set of signals (Figure 6). The signals of the $\mathrm{CH}_{2} \mathrm{~N}_{\text {core }}$ protons $1,1^{\prime}$ of the first-generation dendrimer $\mathbf{3}-\mathbf{Z n C l}_{\mathbf{2}}$ are shifted by $0.2 \mathrm{ppm}$ towards lower field and are split into two doublets. This splitting is consistent with the cis- $\alpha$ configuration observed in the crystal structures of the model complexes $\mathbf{8 -} \mathbf{Z n C l}_{2}$ since the inequivalence of the diastereotopic protons $1,1^{\prime}$ becomes much more pronounced due to the presence of two distinct branches, A and $\mathrm{A}^{\prime}$. Further evidence for one coordinating $\left(\mathrm{A}^{\prime}\right)$ and one non-coordinating dendritic "branch" (A) is provided by the splitting pattern of the $\mathrm{CH}_{2} \mathrm{COO}_{\text {core }}$ protons $2,2^{\prime}$, the $\mathrm{CH}$ protons of the tartaric acid $3,3^{\prime}$, and the benzylic $\mathrm{CH}_{2}$ groups $4,4^{\prime}$.

The $C_{2}$-symmetry in $\mathbf{3}-\mathbf{Z n C l}_{\mathbf{2}}$ eliminates all possible cis- $\beta$ coordination geometries having $C_{1}$-symmetry that would give rise to more complex NMR spectra. These folding motifs can also be ruled out because of the energetically demanding cis-trans isomerization that would be required for the adoption of a trans coordination pattern. This leaves the 
cis- $\alpha$ configurations as the only possibilities, which is in accordance with the structure of the model complex $\mathbf{8}-\mathbf{Z n C l}_{\mathbf{2}}$.

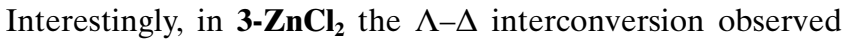
for $\mathbf{8}-\mathbf{Z n C l}_{\mathbf{2}}$ (Scheme 5) is already frozen at room temperature. Lowering the temperature to $-40^{\circ} \mathrm{C}$ does not lead to any significant change in the NMR spectrum. This is probably due to the higher molecular mass of the dendritic

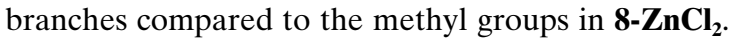

The ${ }^{1} \mathrm{H}$ NMR spectrum of $\mathbf{3}-\mathbf{Z n C l}_{\mathbf{2}}$ shows only one set of signals, indicating that one $c i s-\alpha$ diastereomer (either $\Delta c i s-\alpha$ $(S, S)\left(\right.$ all- $\left.R, R_{\text {dendrimer }}\right) \quad$ or $\quad \Lambda c i s-\alpha(R, R)\left(\right.$ all- $\left.\left.R, R_{\text {dendrimer }}\right)\right) \quad$ is formed predominantly. However, the possibility that the diastereoisomers give rise to almost identical spectra cannot be completely ruled out.

${ }^{1} \mathrm{H}$ NMR spectroscopy of the $\mathrm{Zn}^{\mathrm{II}}$ second-generation den-

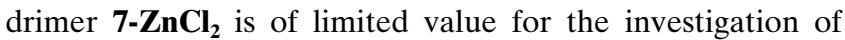
the coordination geometry because of the increased complexity and significant line broadening. This leads to a whole series of closely overlapping signals, which prevents a detailed analysis of coupling patterns and temperature-dependent phenomena.

CD spectroscopy: The paramagnetic nature of the $\mathrm{Cu}^{\mathrm{II}}$ complexes impeded their characterization by NMR spectroscopy. However, the purity of the compounds was proven by reversed-phase HPLC, FAB mass spectrometry, elemental analysis, IR spectroscopy, and UV/Vis spectrophotometry. In particular, UV/Vis spectrophotometry is a useful tool for following the complexation due to the appearance of new metal-centered bands at $\lambda_{\max }=290 \mathrm{~nm}$ (charge-transfer band), $380 \mathrm{~nm}$, and $720 \mathrm{~nm}$ (a weak d-d band) (Figure 7). It

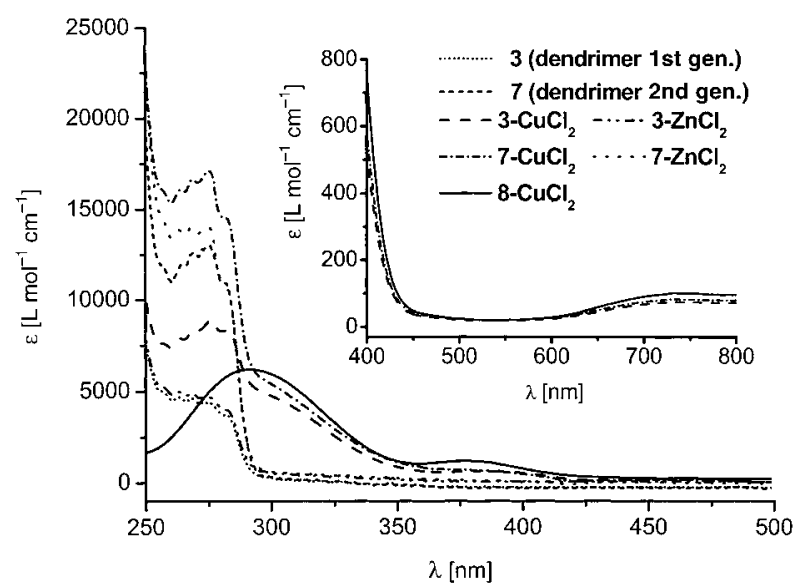

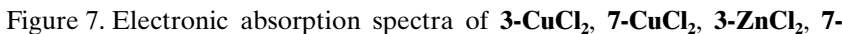
$\mathbf{Z n C l}_{\mathbf{2}}$, and $\mathbf{8 - \mathbf { C u C l } _ { 2 }}$ in $\mathrm{CH}_{3} \mathrm{CN}$

was found that the model complex $\mathbf{8}-\mathbf{C u C l}_{2}$ gave rise to the same absorptions with nearly identical extinction coefficients. Furthermore, these absorptions are clearly separated from the absorptions of the metal-free dendrimers $\left(\lambda_{\max }=\right.$ $260 \mathrm{~nm}$ ) and are therefore suitable for probing the environment at the metal center by means of CD spectroscopy
(Figure 7). First, we discuss the experimental CD spectra of the metallo-dendrimers $\mathbf{3 -} \mathbf{C u C l}_{\mathbf{2}}$ and $\mathbf{7 -} \mathbf{C u C l}_{2}$, in which four distinct metal-centered bands $\mathrm{A}-\mathrm{D}$ can be observed in the range $300-800 \mathrm{~nm}$ (Figure 8 ). These CD bands nicely corre-

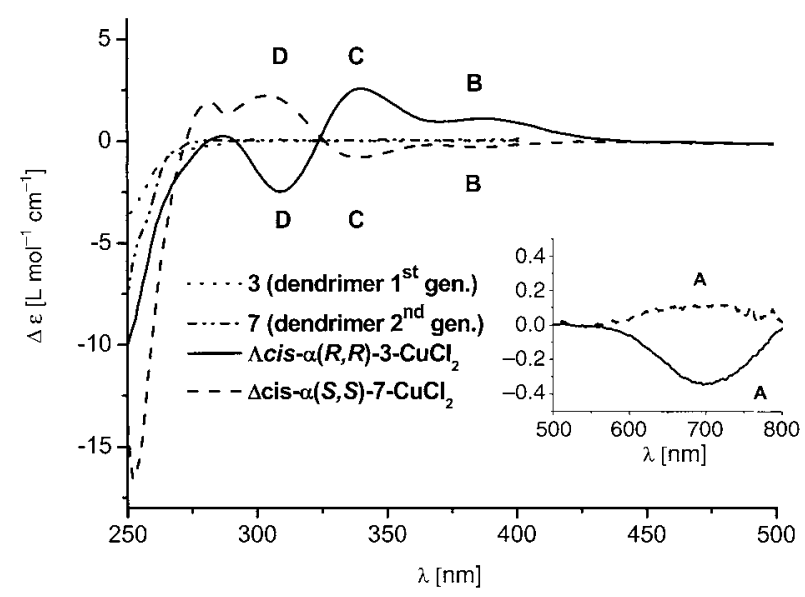

Figure 8. CD spectra of $\mathbf{3 -} \mathbf{C u C l}_{\mathbf{2}}$ and $\mathbf{7 -}-\mathbf{C u C l}_{\mathbf{2}}$ in $\mathrm{CH}_{3} \mathrm{CN}$.

late with the $\mathrm{UV} / \mathrm{Vis}$ absorption bands of $\mathbf{3}-\mathbf{C u C l}_{\mathbf{2}}, \mathbf{7 -} \mathbf{C u C l}_{\mathbf{2}}$, and $\mathbf{8}-\mathbf{C u C l}_{\mathbf{2}}$ (Figure 7). This is clearly indicative of chirality transfer from the ligand to the metal, which, as a result of stereoselectivity, leads to the preferred formation of a chiral coordination motif. It is interesting to note that the CD spectra of the first- and second-generation dendrimers 3-

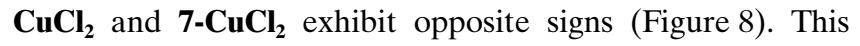
shows that the same coordination motif, but in the opposite configuration, is adopted, namely $\Lambda c i s-\alpha(R, R)$ (all- $\left.R_{\text {dend }}\right)-3-$ $\mathbf{C u C l}_{2}$ and $\Delta c i s-\alpha(S, S)\left(\right.$ all- $\left.R_{\text {dend }}\right)-\mathbf{7 -} \mathbf{C u C l}_{2}$. The determination of the coordination motif and the assignment of the absolute configuration was carried out by comparison with calculated CD spectra (see below). The CD curves are seen to be mirror images above $280 \mathrm{~nm}$, because the two diastereomers possess an enantiomeric coordination motif. Below $280 \mathrm{~nm}$, the chirality of the remote depsipeptide branches dominates the CD spectra. At present, we have no explanation for the fact that the two dendrimers $\mathbf{3}-\mathbf{C u C l}_{\mathbf{2}}$ and $\mathbf{7}-\mathbf{C u C l}_{\mathbf{2}}$, which differ in the steric demand of the dendritic branches, favour different configurations.

For the determination of the coordination motif and the absolute configuration, we decided to calculate the CD spec-

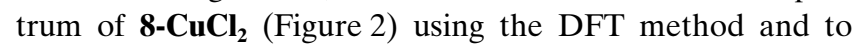
compare the calculated spectrum with the experimental

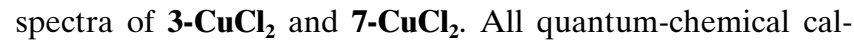
culations were performed with the Turbomole ${ }^{[63]}$ suite of programs. Prior to performing the $\mathrm{CD}$ calculations, the structure of the model compound $\mathbf{8}-\mathbf{C u C l}_{2}$ was fully optimized at the density functional (DFT) level employing the BP86 functional, ${ }^{[64,65]}$ a Gaussian AO basis of valence-triplezeta quality, including polarization functions (TZVP),${ }^{[6]}$ and the RI approximation for the two-electron integrals. ${ }^{[67]}$ The starting geometry was the X-ray crystal structure of $\mathbf{8}-\mathbf{C u C l}_{\mathbf{2}}$ 
in the $\Delta c i s-\alpha(S, S)$ configuration. The optimized structure was used in the subsequent calculation of the CD spectrum, which was performed in the framework of time-dependent DFT ${ }^{[68]}$ as described in detail by Grimme and Diedrich ${ }^{[69,70]}$ and references therein. In this TDDFT approach, the TZVP basis sets and the B3LYP hybrid density functional ${ }^{[71,72]}$ were used.

Comparison of the mirror image of the theoretically simulated spectrum of the model compound $\Delta c i s-\alpha(S, S)-\mathbf{8}-\mathbf{C u C l}_{\mathbf{2}}$ with the experimental spectrum of the copper(II) dendrimer $\mathbf{3 -} \mathbf{C u C l}_{\mathbf{2}}$ reveals very good qualitative correlation (Figure 9).

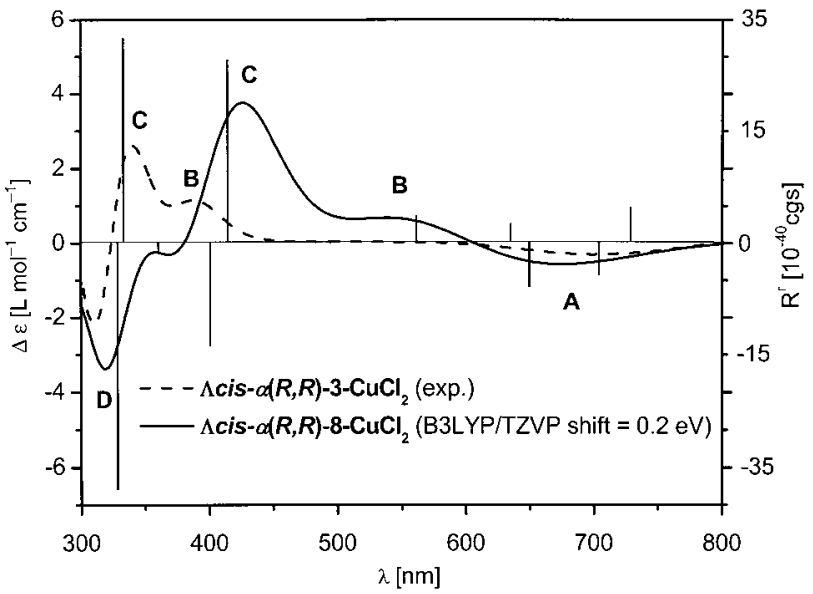

Figure 9. Comparison of the UTDFT-B3 LYP/TZVP simulated and experimental $\mathrm{CD}$ spectra of $\mathbf{3 - C u C l}$. Calculated $\mathrm{CD}$ transitions are shown as vertical lines.

The features in the region $400-600 \mathrm{~nm}$ in the calculated spectrum are red-shifted compared with the experimental spectrum. However, this deviation is not surprising, bearing in mind the structural differences between the model compound and the metallo-dendrimers and the fact that the calculation refers to the gas phase. The absolute configurations of the diastereoselectively preferred foldamers of the chiral metallo-dendrimers could thus be assigned as $\Lambda$ cis- $\alpha-$ $(R, R)\left(\right.$ all- $\left.R_{\text {dend }}\right)-\mathbf{3 - C u C l} \mathbf{C u}_{2}$ and $\Delta c i s-\alpha(S, S)\left(\right.$ all- $\left.R_{\text {dend }}\right)-\mathbf{7 - C u C l} \mathbf{C u}_{\mathbf{2}}$. Accurate predictions of the diastereomeric excess are difficult, as the calculated $\Delta \varepsilon$ values are often subject to an error of up to $50 \% .{ }^{[73]}$ These results are in very good agreement with those of the ${ }^{1} \mathrm{H} \mathrm{NMR}$ spectroscopic investigations

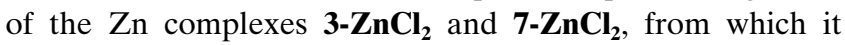
was also concluded that cis- $\alpha$ configurations are present.

\section{Conclusion}

We have synthesized depsipeptide dendrimers 3 and 7 containing an EDTA ester-derived central cavity capable of coordinating $\mathrm{Cu}^{2+}$ and $\mathrm{Zn}^{2+}$ ions. The coordination motif of the related model complexes $\mathbf{8 -} \mathbf{Z n C l}_{\mathbf{2}}$ and $\mathbf{8}-\mathbf{C u C l}_{\mathbf{2}}$ has been investigated by ${ }^{1} \mathrm{H}$ NMR spectroscopy and X-ray analysis, which showed that the model core $\mathbf{8}$ strongly favours a cis- $\alpha$ coordination geometry. In addition, the $\mathrm{CD}$ spectrum of $\Delta c i s-\alpha(S, S)-\mathbf{8}-\mathbf{C u C l}_{\mathbf{2}}$ has been calculated, on the basis of which the absolute configurations of the preferentially formed diastereoisomers of the related chiral dendritic complexes could be assigned as $\Lambda$ cis- $\alpha(R, R)\left(\right.$ all- $\left.R_{\text {dend }}\right)-\mathbf{3}-\mathbf{C u C l}_{\mathbf{2}}$ and $\Delta c i s-\alpha(S, S)\left(\right.$ all- $\left.R_{\text {dend }}\right)-\mathbf{7 - C} \mathbf{C u C l}_{\mathbf{2}}$. Independently, the presence of the cis- $\alpha$ coordination motif has been established from ${ }^{1} \mathrm{H}$ NMR spectroscopic studies of the related $\mathrm{Zn}^{\mathrm{II}}$ dep-

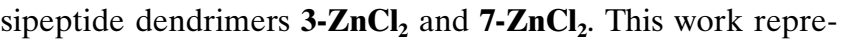
sents the first case of metal-complexation-induced diastereoselective folding of chiral dendrimers with known absolute configuration. In order to obtain even more compact and rigid foldamers of chiral dendrimers, we propose the introduction of a series of chelating moieties within the precursor dendrimer. In addition, further types of oriented interactions, such as hydrogen bonds or electrostatic interactions, should be useful driving forces for such artificial dendrimer folding. Work in this direction is currently underway in our laboratory.

\section{Experimental Section}

General remarks: All starting materials were purchased from commercial sources or were prepared according to known literature procedures. The preparation of $\mathbf{2}$ and $\mathbf{5}$ was described in our previous communication. ${ }^{[33]}$ Solvents were dried using standard techniques. Reactions were monitored by thin-layer chromatography using DC silica gel $60 \mathrm{~F}_{254}$ (Merck) aluminum-backed plates. ${ }^{1} \mathrm{H}$ and ${ }^{13} \mathrm{C}$ NMR spectra were recorded on JEOL GX 400, JEOL EX 400, and JEOL A 500 spectrometers. Chemical shifts are given in ppm relative to $\mathrm{SiMe}_{4}$ or the solvent peak as a standard reference. Resonance multiplicities are indicated as s (singlet), d (doublet), $\mathrm{t}$ (triplet), q (quartet), and $\mathrm{m}$ (multiplet). Broad resonances are denoted as b. Mass spectra were measured with a Micromass Lab Spec (FAB) on a Finnigan MAT 900 spectrometer with 3-nitrobenzylic alcohol as the matrix. IR spectra were recorded on a Bruker FT-IR IFS 88 spectrometer. Circular dichroism (CD) measurements were carried out on a Jasco J 710 machine using optical grade solvents and quartz glass cuvettes with a $10 \mathrm{~mm}$ pathlength. Optical rotations were measured on a Perkin Elmer 341 polarimeter. UV spectroscopy was performed using a Shimadzu UV-3102 spectrophotometer. X-ray crystallographic analysis was performed on an Enraf-Nonius MACH 3 diffractometer. Calculations were carried out using the SHELX software, ${ }^{[74]}$ and the graphics were generated using ORTEP-3. ${ }^{[75]}$ Products were isolated by flash column chromatography (FC) (silica gel 60, particle size 0.04-0.063 nm, Merck).

$(\boldsymbol{R}, \boldsymbol{R})$-2-(Benzoyloxy)-3-hydroxysuccinate (4): $(R, R)$-Dibenzyl-2-(benzoyloxy)-3-hydroxysuccinate $(\mathbf{2})^{[43]}(1.80 \mathrm{~g}, 4.14 \mathrm{mmol})$ was dissolved in $\mathrm{CH}_{3} \mathrm{OH}$ and $10 \% \mathrm{Pd} / \mathrm{C}(200 \mathrm{mg})$ was added. The resulting suspension was subjected to hydrogenation until no more hydrogen was consumed. The solution was then filtered through Celite to remove the catalyst. The $\mathrm{CH}_{3} \mathrm{OH}$ was evaporated and the product was dried in vacuo. Yield: $1030 \mathrm{mg}(99 \%)$ as a white solid; ${ }^{1} \mathrm{H}$ NMR $\left(300 \mathrm{MHz}, \mathrm{CD}_{3} \mathrm{OD}\right): \delta=4.85$ $\left(\mathrm{d},{ }^{3} J=2.4 \mathrm{~Hz}, 1 \mathrm{H} ; * \mathrm{CH}\right), 5.68\left(\mathrm{~d},{ }^{3} J=2.4 \mathrm{~Hz}, 1 \mathrm{H} ; * \mathrm{CH}\right), 7.48(\mathrm{~m}, 2 \mathrm{H}$; $\mathrm{Bz}), 7.63(\mathrm{~m}, 1 \mathrm{H} ; \mathrm{Bz}), 8.11 \mathrm{ppm}(\mathrm{m}, 2 \mathrm{H} ; \mathrm{Bz}) ;{ }^{13} \mathrm{C}$ NMR $(75 \mathrm{MHz}$, $\left.\mathrm{CD}_{3} \mathrm{OD}\right): \delta=72.1,75.8\left({ }^{*} \mathrm{CH}\right), 129.9,131.0,131.4,135.1(\mathrm{Bz}), 167.4$, $170.6,174.1 \mathrm{ppm}(\mathrm{C}=\mathrm{O})$; IR $(\mathrm{KBr}): \tilde{v}=3320,2930,1758,1711,1626$, 1598, 1582, 1490, 1450, 1398, 1340, 1283, 1250, 1221, 1137, 1108, 1073, 1025, $1001 \mathrm{~cm}^{-1}$; MS (FAB): $m / z$ (\%): 255 (25) $[M+\mathrm{H}]^{+}, 154(100)$.

Compound 6, second-generation dendron: $(R, R)-2$-(Benzoyloxy)-3-hydroxysuccinate (4) $(410 \mathrm{mg}, 1.61 \mathrm{mmol})$ was suspended in $\mathrm{CH}_{2} \mathrm{Cl}_{2}$ $(50 \mathrm{~mL})$ and then the deprotected first-generation dendron $\mathbf{5}^{[43]}(2.43 \mathrm{~g}$, $4.16 \mathrm{mmol})$, triethylamine $\left(\mathrm{NEt}_{3}\right)(420 \mathrm{mg}, 0.578 \mathrm{~mL}, 4.16 \mathrm{mmol})$, and HOBt $(562 \mathrm{mg}, 4.16 \mathrm{mmol})$ were added at $0{ }^{\circ} \mathrm{C}$. After the addition of DCC $(860 \mathrm{mg}, 4.16 \mathrm{mmol})$, the mixture was stirred for $24 \mathrm{~h}$. The white 
precipitate of dicyclohexyl urea (DCU) was filtered off, and the $\mathrm{CH}_{2} \mathrm{Cl}_{2}$ layer was washed with a saturated aqueous solution of $\mathrm{NaHCO}_{3}(2 \times$ $50 \mathrm{~mL}$ ) and then dried over $\mathrm{MgSO}_{4}$. After removal of the solvent, the crude product was purified by column chromatography (silica, $\mathrm{CH}_{2} \mathrm{Cl}_{2}$ / $\left.\mathrm{MeOH}, 25: 1 ; R_{\mathrm{f}}=0.27\right)$. Yield: $1146 \mathrm{mg}(54 \%)$ as a white solid; ${ }^{1} \mathrm{H}$ NMR $\left(400 \mathrm{MHz}, \mathrm{CDCl}_{3}\right): \delta=1.43\left(\mathrm{~m}, 12 \mathrm{H} ; \mathrm{CH}_{2}\right), 2.13(\mathrm{~m}, 4 \mathrm{H}$; $\left.\mathrm{CH}_{2} \mathrm{COO}\right), 3.13\left(\mathrm{~m}, 4 \mathrm{H} ; \mathrm{CH}_{2} \mathrm{~N}\right), 4.62\left(\mathrm{br}, 2 \mathrm{H} ; \mathrm{OH}, \mathrm{CH}^{*}\right), 5.02\left(\mathrm{~d},{ }^{2} \mathrm{~J}=\right.$ $\left.5.5 \mathrm{~Hz}, 1 \mathrm{H} ; \mathrm{CH}_{2}-\mathrm{Bn}\right), 5.05\left(\mathrm{~d},{ }^{2} J=5.5 \mathrm{~Hz}, 1 \mathrm{H} ; \mathrm{CH}_{2}-\mathrm{Bn}\right), 5.09\left(\mathrm{~d},{ }^{2} J=\right.$ $\left.6.5 \mathrm{~Hz}, 1 \mathrm{H} ; \mathrm{CH}_{2}-\mathrm{Bn}\right), 5.12\left(\mathrm{~d},{ }^{2} J=6.5 \mathrm{~Hz}, 1 \mathrm{H} ; \mathrm{CH}_{2}-\mathrm{Bn}\right), 5.15\left(\mathrm{~d},{ }^{2} J=\right.$ $\left.6 \mathrm{~Hz}, 1 \mathrm{H} ; \mathrm{CH}_{2}-\mathrm{Bn}\right), 5.18\left(\mathrm{~d},{ }^{2} \boldsymbol{J}=6 \mathrm{~Hz}, 1 \mathrm{H} ; \mathrm{CH}_{2}-\mathrm{Bn}\right), 5.22\left(\mathrm{~d},{ }^{2} \boldsymbol{J}=\right.$ $\left.4 \mathrm{~Hz}, 1 \mathrm{H} ; \mathrm{CH}_{2}-\mathrm{Bn}\right), 5.24\left(\mathrm{~d},{ }^{2} \mathrm{~J}=4 \mathrm{~Hz}, 1 \mathrm{H} ; \mathrm{CH}_{2}-\mathrm{Bn}\right), 5.71\left(\mathrm{~d},{ }^{3} \mathrm{~J}=\right.$ $\left.3 \mathrm{~Hz}, 1 \mathrm{H} ; *^{*} \mathrm{CH}\right), 5.78\left(\mathrm{~d},{ }^{3} \mathrm{~J}=3 \mathrm{~Hz}, 1 \mathrm{H} ; * \mathrm{CH}\right), 5.80\left(\mathrm{~d},{ }^{3} \mathrm{~J}=3 \mathrm{~Hz}, 1 \mathrm{H}\right.$; $\left.{ }^{*} \mathrm{CH}\right), 5.82\left(\mathrm{~d},{ }^{3} \mathrm{~J}=3 \mathrm{~Hz}, 1 \mathrm{H} ; * \mathrm{CH}\right), 5.89\left(\mathrm{~d},{ }^{3} \mathrm{~J}=3 \mathrm{~Hz}, 1 \mathrm{H} ; * \mathrm{CH}\right), 5.91$ $\left(\mathrm{d},{ }^{3} \mathrm{~J}=3 \mathrm{~Hz}, 1 \mathrm{H} ; * \mathrm{CH}\right), 6.49(\mathrm{br}, 1 \mathrm{H} ; \mathrm{NH}), 6.92(\mathrm{br}, 1 \mathrm{H} ; \mathrm{NH}), 7.09(\mathrm{~m}$, 6H; Bn), 7.15 (m, 4H; Bn), $7.28(\mathrm{~m}, 10 \mathrm{H} ; \mathrm{Bn}), 7.40(\mathrm{~m}, 6 \mathrm{H} ; \mathrm{Ph}), 7.56$ $(\mathrm{m}, 3 \mathrm{H} ; \mathrm{Bz}), 7.91(\mathrm{~m}, 4 \mathrm{H} ; \mathrm{Bz}), 8.01 \mathrm{ppm}(\mathrm{m}, 2 \mathrm{H} ; \mathrm{Bz}) ;{ }^{13} \mathrm{C}$ NMR $\left(100.6 \mathrm{MHz}, \mathrm{CDCl}_{3}\right): \delta=23.2,24.0,24.1,25.8,25.9,26.0,28.7,28.9,29.2$ $\left(\mathrm{CH}_{2}\right), 33.1,33.2\left(\mathrm{CH}_{2} \mathrm{COO}\right), 38.9,39.2,39.3\left(\mathrm{CH}_{2} \mathrm{~N}\right), 53.4,67.7,67.8$, $67.9\left(\mathrm{CH}_{2}-\mathrm{Bn}\right), 70.7,71.2,71.7,73.1(* \mathrm{CH}), 128.2,128.3,128.42,128.47$, $128.6,128.7,129.9,130.0,133.6,133.7,133.9,134.4,134.5,134.8(\mathrm{Ph})$, 155.9, 164.9, 165.5, 165.6, 165.7, 168.6, 169.3, 172.0, $172.1 \mathrm{ppm}(\mathrm{C}=\mathrm{O})$; IR $(\mathrm{KBr}): \tilde{v}=3396,3066,2940,1734,1655,1601,1542,1498,1453,1382$, $1262,1213,1139,1094,1070,1025,962,714,698 \mathrm{~cm}^{-1}$; MS (FAB): $\mathrm{m} / z$ (\%): $1313(40)[M+\mathrm{H}]^{+}, 925$ (39), 590 (100); elemental analysis calcd (\%) for $\mathrm{C}_{73} \mathrm{H}_{72} \mathrm{O}_{21} \mathrm{~N}_{2} \cdot \mathrm{H}_{2} \mathrm{O}$ (1331.37): C 65.86, H 5.60, N 2.10; found: $\mathrm{C}$ $65.80, \mathrm{H} 5.75, \mathrm{~N} 2.49 ;[\alpha]_{\mathrm{D}}^{20}=+43.0\left(c=0.108, \mathrm{CH}_{2} \mathrm{Cl}_{2}\right)$.

Compound 3, first-generation dendrimer: Ethylenediaminetetraacetic acid (EDTA) (915 mg, $3.13 \mathrm{mmol}$ ), 4-dimethylaminopyridine (DMAP) (306 mg, $2.5 \mathrm{mmol}$ ), and ( $R, R)$-dibenzyl-2-(benzoyloxy)-3-hydroxysuccinate ${ }^{[43]}(6.8 \mathrm{~g}, 15.7 \mathrm{mmol})$ were suspended in $\mathrm{CH}_{2} \mathrm{Cl}_{2}(100 \mathrm{~mL})$. Dicyclohexyl carbodiimide (DCC) $(2.6 \mathrm{~g}, 12.5 \mathrm{mmol})$ was added in one portion at room temperature and the resulting suspension was stirred for 10 days. The white precipitate of dicyclohexyl urea (DCU) was then filtered off, and the organic solution was washed with saturated aqueous $\mathrm{NaHCO}_{3}$ solution $(2 \times 100 \mathrm{~mL})$ and with saturated $\mathrm{NaCl}$ solution $(1 \times 100 \mathrm{~mL})$, and then dried over $\mathrm{MgSO}_{4}$. After evaporation of the solvent under reduced pressure, the crude product was purified by column chromatography (silica, $\left.\mathrm{CH}_{2} \mathrm{Cl}_{2} / \mathrm{MeOH}, 40: 1 ; R_{\mathrm{f}}=0.68\right)$. Yield: $3370 \mathrm{mg}(55 \%$ ) as a white solid; ${ }^{1} \mathrm{H}$ NMR $\left(400 \mathrm{MHz}, \mathrm{CDCl}_{3}\right): \delta=2.79\left(\mathrm{~d},{ }^{2} \mathrm{~J}=10 \mathrm{~Hz}, 2 \mathrm{H}\right.$; $\left.\mathrm{CH}_{2} \mathrm{~N}_{\mathrm{EDTA}}\right), 2.81\left(\mathrm{~d},{ }^{2} \boldsymbol{J}=10 \mathrm{~Hz}, 2 \mathrm{H} ; \mathrm{CH}_{2} \mathrm{~N}_{\mathrm{EDTA}}\right), 3.55\left(\mathrm{~d},{ }^{2} \boldsymbol{J}=18 \mathrm{~Hz}\right.$, $\left.4 \mathrm{H} ; \mathrm{CH}_{2} \mathrm{COOR}_{\mathrm{EDTA}}\right), 3.62\left(\mathrm{~d},{ }^{2} \boldsymbol{J}=18 \mathrm{~Hz}, 4 \mathrm{H} ; \mathrm{CH}_{2} \mathrm{COOR}_{\mathrm{EDTA}}\right), 4.89$ (d, $\left.{ }^{2} J=12 \mathrm{~Hz}, 8 \mathrm{H} ; \mathrm{CH}_{2}-\mathrm{Bn}\right), 5.11\left(\mathrm{~d},{ }^{2} J=12 \mathrm{~Hz}, 8 \mathrm{H} ; \mathrm{CH}_{2}-\mathrm{Bn}\right), 5.83\left(\mathrm{~d},{ }^{3} \boldsymbol{J}\right.$ $\left.=3 \mathrm{~Hz}, 4 \mathrm{H} ; \mathrm{CH}^{*}\right), 5.90\left(\mathrm{~d},{ }^{3} \mathrm{~J}=3 \mathrm{~Hz}, 4 \mathrm{H} ; * \mathrm{CH}\right), 7.05(\mathrm{~m}, 20 \mathrm{H} ; \mathrm{Bn})$, $7.11(\mathrm{~m}, 20 \mathrm{H} ; \mathrm{Bn}), 7.31(\mathrm{~m}, 8 \mathrm{H} ; \mathrm{Bz}), 7.43(\mathrm{~m}, 4 \mathrm{H} ; \mathrm{Bz}), 7.88 \mathrm{ppm}(\mathrm{m}$, $8 \mathrm{H} ; \mathrm{Bz}) ;{ }^{13} \mathrm{C}$ NMR $\left(100.6 \mathrm{MHz}, \mathrm{CDCl}_{3}\right): \delta=51.2\left(\mathrm{CH}_{2} \mathrm{~N}_{\mathrm{EDTA}}\right), 54.3$ $\left(\mathrm{NCH}_{2} \mathrm{CO}_{\text {EDTA }}\right), 67.8\left(\mathrm{CH}_{2}-\mathrm{Bn}\right), 71.0,71.2(* \mathrm{CH}), 128.1,128.3,128.4$, 128.6, 130.0, 133.5, 134.5, $134.8(\mathrm{Ph}), 165.0,165.4,171.1 \mathrm{ppm}(\mathrm{C}=\mathrm{O})$; MS (FAB): $m / z(\%): 1958(80)[M+\mathrm{H}]^{+}, 1867(5)[M-\mathrm{Bn}]^{+}, 1495(20), 992$ (40), $978(100)[M+\mathrm{H}]^{2+}$; IR $(\mathrm{KBr}): \tilde{v}=3065,3034,2962,1768,1733$, $1601,1586,1498,1455,1262,1123,1091,1069 \mathrm{~cm}^{-1}$; UV/Vis $\left(\mathrm{CH}_{3} \mathrm{CN}\right)$ : $\lambda_{\max }(\varepsilon)=268(4600), 231 \mathrm{~nm}(47500) ; \mathrm{CD}\left(\mathrm{CH}_{3} \mathrm{CN}\right): \lambda_{\max }(\Delta \varepsilon)=229$ $(-10), 216(-8), 202 \mathrm{~nm}(-26)$; elemental analysis calcd $(\%)$ for $\mathrm{C}_{110} \mathrm{H}_{96} \mathrm{O}_{32} \mathrm{~N}_{2}$ (1956.5): C 67.48, H 4.94, N 1.43; found: $\mathrm{C} 67.55, \mathrm{H} 4.85, \mathrm{~N}$ $1.41 ;[\alpha]_{\mathrm{D}}^{20}=+30.0\left(c=1.1120, \mathrm{CH}_{2} \mathrm{Cl}_{2}\right)$.

Compound 7, second-generation dendrimer: Ethylenediaminetetraacetic acid (EDTA) 1 (13 mg, $0.044 \mathrm{mmol}$ ), 4-dimethylaminopyridine (DMAP) $(9 \mathrm{mg}, 0.077 \mathrm{mmol})$, and the second-generation dendron compound 6 $(289 \mathrm{mg}, 0.22 \mathrm{mmol})$ were suspended in dry $\mathrm{CH}_{2} \mathrm{Cl}_{2}(100 \mathrm{~mL})$. 1-(3-Dimethylaminopropyl)-3-ethylcarbodiimide hydrochloride (EDC. $\mathrm{HCl})(72 \mathrm{mg}$, $0.375 \mathrm{mmol}$ ) was added and the resulting suspension was stirred for 10 days at room temperature. The white precipitate was then filtered off and, after evaporation of the solvent under reduced pressure, the crude product was purified by column chromatography (silica, $\mathrm{CH}_{2} \mathrm{Cl}_{2} / \mathrm{MeOH}$, $\left.25: 1 ; R_{\mathrm{f}}=0.68\right)$. Yield: $44 \mathrm{mg}(18 \%)$ as a white solid; ${ }^{1} \mathrm{H}$ NMR $\left(400 \mathrm{MHz}, \mathrm{CDCl}_{3}\right): \delta=1.3\left(\mathrm{~m}, 48 \mathrm{H} ; \mathrm{CH}_{2}\right), 1.97\left(\mathrm{~m}, 4 \mathrm{H} ; \mathrm{CH}_{2} \mathrm{COO}\right)$, $2.08\left(\mathrm{~m}, 8 \mathrm{H} ; \mathrm{CH}_{2} \mathrm{COO}\right), 2.25\left(\mathrm{~m}, 4 \mathrm{H} ; \mathrm{CH}_{2} \mathrm{COO}\right), 2.87\left(\mathrm{~m}, 4 \mathrm{H} ; \mathrm{CH}_{2} \mathrm{~N}_{\mathrm{ED}}\right.$. TA $), 3.12\left(\mathrm{~m}, 16 \mathrm{H} ; \mathrm{CH}_{2} \mathrm{~N}\right), 3.62\left(\mathrm{~d},{ }^{2} J=7.5 \mathrm{~Hz}, 4 \mathrm{H} ; \mathrm{CH}_{2} \mathrm{COO}_{\text {EDTA }}\right), 3.85$ $\left(\mathrm{d},{ }^{2} \mathrm{~J}=7.5 \mathrm{~Hz}, 4 \mathrm{H} ; \mathrm{CH}_{2} \mathrm{COO}_{\mathrm{EDTA}}\right), 5.15\left(\mathrm{~m}, 32 \mathrm{H} ; \mathrm{CH}_{2}-\mathrm{Bn}\right), 5.85(\mathrm{~m}$, $\left.24 \mathrm{H} ;{ }^{*} \mathrm{CH}\right), 6.51$ (br, 4H; NH), 6.95 (br, 4H; NH), 7.10 (m, 36H; Bn),
7.25 (m, 44H; Bn), 7.35 (m, 24H; Bz), 7.55 (m, 12 H; Bz), 7.91 (m, 16H; $\mathrm{Bz}), 8.05 \mathrm{ppm}(\mathrm{m}, 8 \mathrm{H} ; \mathrm{Bz}) ;{ }^{13} \mathrm{C} \mathrm{NMR}\left(100.6 \mathrm{MHz}, \mathrm{CDCl}_{3}\right): \delta=24.0$, 25.9, 26.0, 28.8, 29.1, 29.6 $\left(\mathrm{CH}_{2}\right), 33.1\left(\mathrm{CH}_{2} \mathrm{COO}\right), 38.9,39.3\left(\mathrm{CH}_{2} \mathrm{~N}\right), 51.8$ $\left(\mathrm{CH}_{2} \mathrm{~N}_{\text {EDTA }}\right), 54.7\left(\mathrm{CH}_{2} \mathrm{COO}_{\text {EDTA }}\right), 66.3,67.7,67.8,68.1\left(\mathrm{CH}_{2}-\mathrm{Bn}\right), 70.7$, 71.1, 71.2, 71.1, 72.5, 72.9, $73.1(* \mathrm{CH}), 128.0,128.3,128.4,128.6,128.7$, $128.8,130.0,130.3,133.6,134.0,134.5,134.8(\mathrm{Ph}), 164.8,164.9,165.0$, $165.5,165.7,165.9,166.2,166.3,168.3,168.5,169.9,170.1,172.1 \mathrm{ppm}(\mathrm{C}=$ O); MS (FAB): $m / z(\%): 5474(40)[M+H]^{+}, 4269$ (35), $2736(25), 1396$ (18), 1313 (20), 548 (100); IR (KBr): $\tilde{v}=3066,3034,2943,2863,1734$, 1680, 1601, 1585, 1535, 1498, 1454, 1382, 1351, 1316, 1261, 1213, 1195, 1147, 1128, 1094, 1070, $1025 \mathrm{~cm}^{-1}$; UV/Vis $\left(\mathrm{CH}_{3} \mathrm{CN}\right): \lambda_{\max }(\varepsilon)=274$ (13000), $231 \mathrm{~nm}(142000) ; \mathrm{CD}\left(\mathrm{CH}_{3} \mathrm{CN}\right): \lambda_{\max }(\Delta \varepsilon)=239(-17), 213 \mathrm{~nm}$ (37); elemental analysis calcd (\%) for $\mathrm{C}_{302} \mathrm{H}_{296} \mathrm{O}_{88} \mathrm{~N}_{10}$ (5473.6): $\mathrm{C} 66.27, \mathrm{H}$ $5.45, \mathrm{~N} 2.56$; found: C 66.20, H 5.50, N 2.32; $[\alpha]_{\mathrm{D}}^{20}=-51.0(c=0.058$, $\mathrm{CH}_{2} \mathrm{Cl}_{2}$ ).

General procedure for the preparation of the dendritic metal complexes : The dendrimer $(0.05 \mathrm{mmol})$ was dissolved in $\mathrm{CH}_{2} \mathrm{Cl}_{2}(10 \mathrm{~mL})$ or $\mathrm{CHCl}_{3}$ $(10 \mathrm{~mL})$ and a large excess of the metal salt $(0.30 \mathrm{mmol})$ was added in one portion. After stirring overnight at room temperature, the suspension was filtered (Iso-Disc, $0.45 \mu \mathrm{m}$ ) to remove the uncomplexed metal salt. After evaporation of the solvent under reduced pressure, the product was dried in vacuo.

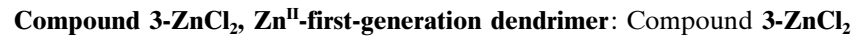
was synthesized according to the general procedure from dendrimer $\mathbf{3}$ (98 mg, $0.05 \mathrm{mmol}$ ) and $\mathrm{ZnCl}_{2}$ (41 mg, $0.30 \mathrm{mmol}$ ). C,H,N elemental analysis was carried out on a sample prepared in $\mathrm{CH}_{2} \mathrm{Cl}_{2}$. Yield: $114 \mathrm{mg}$ (99\%) as a white solid; ${ }^{1} \mathrm{H}$ NMR $\left(400 \mathrm{MHz}, \mathrm{CDCl}_{3}\right): \delta=2.95(\mathrm{~m}, 2 \mathrm{H}$; $\mathrm{CH}_{2} \mathrm{~N}_{\mathrm{EDTA}}$ ), 3.10 (br, $\left.2 \mathrm{H} ; \mathrm{CH}_{2} \mathrm{~N}_{\mathrm{EDTA}}\right), 3.70\left(\mathrm{~d},{ }^{2} \mathrm{~J}=18 \mathrm{~Hz}, 2 \mathrm{H}\right.$; $\left.\mathrm{CH}_{2} \mathrm{COOR}_{\text {EDTA }}\right), 3.86\left(\mathrm{~d},{ }^{2} \boldsymbol{J}=18 \mathrm{~Hz}, 2 \mathrm{H} ; \mathrm{CH}_{2} \mathrm{COOR}_{\mathrm{EDTA}}\right), 3.92\left(\mathrm{~d},{ }^{2} \boldsymbol{J}=\right.$ $\left.18 \mathrm{~Hz}, 2 \mathrm{H} ; \mathrm{CH}_{2} \mathrm{COOR}_{\text {EDTA }}\right), 4.14\left(\mathrm{~d},{ }^{2} J=18 \mathrm{~Hz}, 2 \mathrm{H} ; \mathrm{CH}_{2} \mathrm{COOR}_{\mathrm{EDTA}}\right)$, $4.71\left(\mathrm{~d},{ }^{2} \mathrm{~J}=12 \mathrm{~Hz}, 2 \mathrm{H} ; \mathrm{CH}_{2}-\mathrm{Bn}\right), 5.03\left(\mathrm{~d},{ }^{2} \mathrm{~J}=12 \mathrm{~Hz}, 2 \mathrm{H} ; \mathrm{CH}_{2}-\mathrm{Bn}\right)$, $5.16\left(\mathrm{~m}, 10 \mathrm{H} ; \mathrm{CH}_{2}-\mathrm{Bn}\right), 5.25\left(\mathrm{~d},{ }^{2} J=12 \mathrm{~Hz}, 2 \mathrm{H} ; \mathrm{CH}_{2}-\mathrm{Bn}\right), 5.93\left(\mathrm{~d},{ }^{3} J=\right.$ $3 \mathrm{~Hz}, 2 \mathrm{H} ; * \mathrm{CH}), 5.98\left(\mathrm{~d},{ }^{3} \mathrm{~J}=3 \mathrm{~Hz}, 2 \mathrm{H} ; * \mathrm{CH}\right), 6.02\left(\mathrm{~d},{ }^{3} \mathrm{~J}=3 \mathrm{~Hz}, 2 \mathrm{H}\right.$; $\left.{ }^{*} \mathrm{CH}\right), 6.18\left(\mathrm{~d},{ }^{3} \mathrm{~J}=3 \mathrm{~Hz}, 2 \mathrm{H} ; * \mathrm{CH}\right), 6.90(\mathrm{~m}, 12 \mathrm{H} ; \mathrm{Bn}), 7.29(\mathrm{~m}, 34 \mathrm{H}$; $\mathrm{Ph}), 7.37$ (m, 4H; Bz), 7.55 (m, 2H; Bz), $7.82(\mathrm{~m}, 4 \mathrm{H} ; \mathrm{Bz}), 7.87 \mathrm{ppm}(\mathrm{m}$, $4 \mathrm{H} ; \mathrm{Bz}) ;{ }^{13} \mathrm{C}$ NMR $\left(100.6 \mathrm{MHz}, \mathrm{CDCl}_{3}\right): \delta=53.0\left(\mathrm{CH}_{2} \mathrm{~N}_{\mathrm{EDTA}}\right), 56.9$ $\left(\mathrm{CH}_{2} \mathrm{COO}_{\mathrm{EDTA}}\right), 68.3,68.6,69.0,69.9,70.7,72.4,127.9,128.1,128.2,128.5$, $128.6,128.7,128.8,128.9,129.2,129.9,130.0,130.1,133.7,134.0,134.5$ $134.6(\mathrm{Ph}), 164.4,164.6,164.8,165.3,180.1 \mathrm{ppm}(\mathrm{C}=\mathrm{O})$; MS (FAB): $\mathrm{m} / \mathrm{z}$ (\%): $2189(10)[M+\mathrm{Cs}-\mathrm{Cl}]^{+}, 2057(50)[M-\mathrm{Cl}]^{+}, 1957(80)\left[M-\mathrm{ZnCl}_{2}\right]$, 1603 (30), 1496 (20), 992 (100); IR (KBr): $\tilde{v}=3441,3034,2957,1736$, $1601,1498,1455,1384,1263,1214,1091,1069,1025,961 \mathrm{~cm}^{-1} ; \mathrm{UV} / \mathrm{Vis}$ $\left(\mathrm{CH}_{3} \mathrm{CN}\right): \lambda_{\max }(\varepsilon)=274(4500), 231 \mathrm{~nm}(48000)$; elemental analysis calcd (\%) for $\mathrm{C}_{110} \mathrm{H}_{96} \mathrm{O}_{32} \mathrm{~N}_{2} \mathrm{Cl}_{2} \mathrm{Zn} \cdot 2 \mathrm{CH}_{2} \mathrm{Cl}_{2} \cdot \mathrm{H}_{2} \mathrm{O}$ (2282.1): $\mathrm{C} 58.95, \mathrm{H} 4.51$, $\mathrm{N} \mathrm{1.23;} \mathrm{found:} \mathrm{C} \mathrm{58.84,} \mathrm{H} \mathrm{4.47,} \mathrm{N} \mathrm{0.98;}[\alpha]_{\mathrm{D}}^{20}=+54.0(c=0.114$ $\mathrm{CH}_{2} \mathrm{Cl}_{2}$ ).

Compound 7- $\mathbf{Z n C l}_{2}, \mathbf{Z n}^{\text {II }}$-second-generation dendrimer: Compound 7$\mathbf{Z n C l}_{\mathbf{2}}$ was synthesized according to the general procedure from dendrimer 7 (30 mg, $5.5 \mu \mathrm{mol})$ and $\mathrm{ZnCl}_{2}(10 \mathrm{mg}, 0.07 \mathrm{mmol})$. C,H,N elemental analysis was carried out on a sample prepared in $\mathrm{CHCl}_{3}$. Yield: $30 \mathrm{mg}$ $(99 \%)$ as a white solid; ${ }^{1} \mathrm{H}$ NMR $\left(400 \mathrm{MHz}, \mathrm{CDCl}_{3}\right): \delta=1.33(\mathrm{~m}, 48 \mathrm{H}$; $\mathrm{CH}_{2}$ ), 2.10 (m, $\left.16 \mathrm{H} ; \mathrm{CH}_{2} \mathrm{COO}\right), 2.90$ (br, 4H; $\left.\mathrm{CH}_{2} \mathrm{~N}_{\mathrm{EDTA}}\right), 3.20(\mathrm{~m}, 16 \mathrm{H}$; $\left.\mathrm{CH}_{2} \mathrm{~N}\right), 4.27\left(\mathrm{~m}, 8 \mathrm{H} ; \mathrm{CH}_{2} \mathrm{COO}_{\mathrm{EDTA}}\right), 5.10\left(\mathrm{~m}, 32 \mathrm{H} ; \mathrm{CH}_{2}-\mathrm{Bn}\right), 5.78(\mathrm{~m}$ $12 \mathrm{H} ; * \mathrm{CH}), 5.9\left(\mathrm{~m}, 12 \mathrm{H} ;{ }^{*} \mathrm{CH}\right), 6.35(\mathrm{br}, 4 \mathrm{H} ; \mathrm{NH}), 6.60$ (br, $\left.4 \mathrm{H} ; \mathrm{NH}\right)$, $7.10(\mathrm{~m}, 36 \mathrm{H} ; \mathrm{Bn}), 7.25(\mathrm{~m}, 44 \mathrm{H} ; \mathrm{Bn}), 7.40(\mathrm{~m}, 24 \mathrm{H} ; \mathrm{Bz}), 7.54(\mathrm{~m}, 12 \mathrm{H}$ $\mathrm{Bz}), 7.92(\mathrm{~m}, 16 \mathrm{H} ; \mathrm{Bz}), 8.05 \mathrm{ppm}(\mathrm{m}, 8 \mathrm{H} ; \mathrm{Bz}) ;{ }^{13} \mathrm{C}$ NMR $(100.6 \mathrm{MHz}$ $\left.\mathrm{CDCl}_{3}\right): \delta=24.0,24.1,24.3,24.5,25.9,26.3,28.4,28.9,29.0,29.6,29.7$ $\left(\mathrm{CH}_{2}\right), 33.1,33.2,33.7,33.9\left(\mathrm{CH}_{2} \mathrm{COO}\right), 38.7,39.2,39.3,40.1\left(\mathrm{CH}_{2} \mathrm{~N}\right)$, 51.4, 52.7, 53.4, 67.7, $67.9\left(\mathrm{CH}_{2}-\mathrm{Bn}\right), 70.7,71.2,71.3,72.3,72.8(* \mathrm{CH})$, 128.3, 128.4, 128.5, 128.6, 128.7, 129.9, 130.0, 133.6, 133.9, 134.5, 134.8 $(\mathrm{Ph}), 165.0,165.5,165.7,166.0,166.1,170.3,171.8,172.0 \mathrm{ppm}(\mathrm{C}=\mathrm{O}) ; \mathrm{MS}$ (FAB): $m / z(\%): 5573(50)[M-C l]^{+}, 5057$ (10), 4241 (20), 2769 (18), 1313 (50), 548 (100); IR (KBr): $\tilde{v}=2947,1734,1638,1544,1498,1454$, 1382, 1261, 1213, 1196, 1128, 1094, 1070, $1025 \mathrm{~cm}^{-1}$; UV/Vis $\left(\mathrm{CH}_{3} \mathrm{CN}\right)$ : $\lambda_{\max }(\varepsilon)=274(14000), 231 \mathrm{~nm}(145000)$; elemental analysis calcd $(\%)$ for $\mathrm{C}_{302} \mathrm{H}_{296} \mathrm{O}_{88} \mathrm{~N}_{10} \mathrm{ZnCl}_{2} \cdot 3 \mathrm{CHCl}_{3}$ (5968.0): C 61.38, H 5.05, N 2.35; found: C 61.38, H 5.07, N 2.02; $[\alpha]_{\mathrm{D}}^{20}=-34.0\left(c=0.174, \mathrm{CH}_{2} \mathrm{Cl}_{2}\right)$. 
Compound 3- $\mathrm{CuCl}_{2}, \mathrm{Cu}^{\mathrm{II}}$-first-generation dendrimer: Compound 3- $\mathrm{CuCl}_{\mathbf{2}}$ was synthesized according to the general procedure from dendrimer $\mathbf{3}$ (28 mg, $0.014 \mathrm{mmol})$ and $\mathrm{CuCl}_{2}$ (12 mg, $\left.0.09 \mathrm{mmol}\right)$. Yield: $29 \mathrm{mg}(99 \%)$ as a light-green solid; MS (FAB): $m / z$ (\%): $2056(30)[M-C l]^{+}, 2021(40)$ $[M-2 \mathrm{Cl}]^{+}, 1958(40)\left[M-\mathrm{CuCl}_{2}\right]^{+}, 1495$ (18), 1083 (20), 978 (100); IR $(\mathrm{KBr}): \tilde{v}=3066,3035,2956,1733,1602,1586,1498,1455,1382,1349$, 1316, 1263, 1197, 1126, 1091, 1069, 961, $823 \mathrm{~cm}^{-1}$; elemental analysis calcd (\%) for $\mathrm{C}_{110} \mathrm{H}_{96} \mathrm{O}_{32} \mathrm{~N}_{2} \mathrm{CuCl}_{2}$ (2092.4): $\mathrm{C}$ 63.14, $\mathrm{H}$ 4.62, N 1.34; found: $\mathrm{C}$ 63.34, $\mathrm{H} \mathrm{4.75,} \mathrm{N} \mathrm{1.20;} \mathrm{UV/Vis}\left(\mathrm{CH}_{3} \mathrm{CN}\right): \lambda_{\max }(\varepsilon)=720(75)$, 370 (1000), 310 (5200), 260 (9000), 276 (14100), $231 \mathrm{~nm}$ (62900); CD $\left(\mathrm{CH}_{3} \mathrm{CN}\right): \lambda_{\max }(\Delta \varepsilon)=700(-0.3), 387$ (1.1), 340 (2.6), 309 (2.5), 230 $(-10), 203 \mathrm{~nm}(-30) ;[\alpha]_{\mathrm{D}}^{20}=+118\left(c=0.126, \mathrm{CH}_{2} \mathrm{Cl}_{2}\right)$.

Compound 7- $\mathrm{CuCl}_{2}, \mathrm{Cu}^{\mathrm{II}}$-second-generation dendrimer: Compound 7$\mathbf{C u C l}_{2}$ was synthesized according to the general procedure from dendrimer $7(24 \mathrm{mg}, 4.4 \mu \mathrm{mol})$ and $\mathrm{CuCl}_{2}(4 \mathrm{mg}, 0.03 \mathrm{mmol})$. Yield: $24 \mathrm{mg}(99 \%)$ as a light-green solid; MS (FAB): $m / z(\%): 5570(10)[M-C l]^{+}, 5536(10)$ $[M-2 \mathrm{Cl}]^{+}, 5473(20)\left[M-\mathrm{CuCl}_{2}\right]^{+}, 4267(25), 2736(20), 1495(18), 1313$ (50), 978 (80), 548 (100); IR (KBr): $\tilde{v}=3450,3035,2956,1733,1681$, 1602, 1537, 1498, 1453, 1261, 1214, 1197, 1094, 1069, $1026 \mathrm{~cm}^{-1}$; elemental analysis calcd (\%) for $\mathrm{C}_{302} \mathrm{H}_{296} \mathrm{O}_{88} \mathrm{~N}_{10} \mathrm{CuCl}_{2}$ (5608.1): $\mathrm{C}$ 64.68, H 5.32, N 2.50; found: C 64.70, H 5.55, N 2.16; UV/Vis $\left(\mathrm{CH}_{3} \mathrm{CN}\right): \lambda_{\max }(\varepsilon)=720$ (85), 370 (1000), 310 (5800), 276 (18000), 260 (14000), $231 \mathrm{~nm}$ (148000); $\mathrm{CD}\left(\mathrm{CH}_{3} \mathrm{CN}\right): \lambda_{\max }(\Delta \varepsilon)=700(0.15), 384(-0.3), 338(-0.8), 305(2.2)$, $252(-16), 215(6), 205 \mathrm{~nm}(0.3) ;[\alpha]_{\mathrm{D}}^{20}=-41.0\left(c=0.066, \mathrm{CH}_{2} \mathrm{Cl}_{2}\right)$.

Compound $8-\mathbf{Z n C l}_{2}$, model core- $\mathbf{Z n C l}_{2}$ : Compound $\mathbf{8}-\mathbf{Z n C l}_{\mathbf{2}}$ was synthesized according to the general procedure from ethylenediaminetetraacetic acid tetramethyl ester ${ }^{[59]}(235 \mathrm{mg}, 0.675 \mathrm{mmol})$ and $\mathrm{ZnCl}_{2}(109 \mathrm{mg}$, $0.8 \mathrm{mmol}$ ). Single crystals suitable for $\mathrm{X}$-ray and $\mathrm{C}, \mathrm{H}, \mathrm{N}$ analysis were obtained by slow diffusion of $\mathrm{Et}_{2} \mathrm{O}$ into a solution of $\mathbf{8}-\mathbf{Z n C l}_{\mathbf{2}}$ in $\mathrm{CH}_{3} \mathrm{CN}$ at room temperature. Yield: $324 \mathrm{mg}(98 \%)$ as a white solid; ${ }^{1} \mathrm{H}$ NMR $\left(400 \mathrm{MHz}, \mathrm{CDCl}_{3}\right): \delta=3.03$ (br, $\left.4 \mathrm{H} ; \mathrm{CH}_{2} \mathrm{~N}_{\mathrm{EDTA}}\right), 3.79$ (s, $12 \mathrm{H} ; \mathrm{CH}_{3}$ ), $3.98 \mathrm{ppm}\left(\mathrm{s}, 8 \mathrm{H} ; \mathrm{CH}_{2} \mathrm{COO}_{\text {EDTA }}\right) ;{ }^{13} \mathrm{C}$ NMR $\left(100.6 \mathrm{MHz}, \mathrm{CDCl}_{3}\right): \delta=$ 51.4, 53.2, 55.2, $172.7 \mathrm{ppm}$; MS (FAB): $\mathrm{m} / z(\%): 447(100)[M+\mathrm{H}]^{+}, 349$ (95) $\left[M-\mathrm{ZnCl}_{2}\right]^{+}, 289(20), 188(50) ; \mathrm{IR}(\mathrm{KBr}): \tilde{v}=3460,2954,1740$, 1697, 1445, 1386, 1311, 1243, 1212, 1122, 1066, 1012, 994, 906, $812 \mathrm{~cm}^{-1}$; elemental analysis calcd (\%) for $\mathrm{C}_{14} \mathrm{H}_{24} \mathrm{O}_{8} \mathrm{~N}_{2} \mathrm{ZnCl}_{2} \cdot \mathrm{CH}_{3} \mathrm{CN}$ (525.8): C 36.56, H 5.18, N 7.99; found: C 36.63, H 5.28, N 8.16.

Compound 8- $\mathbf{C u C l}_{2}$, model core- $\mathrm{CuCl}_{2}$ : Compound $8-\mathbf{C u C l}_{2}$ was synthesized according to the general procedure from ethylenediaminetetraacetic acid tetramethyl ester ${ }^{[59]}(200 \mathrm{mg}, 0.575 \mathrm{mmol})$ and $\mathrm{CuCl}_{2}(94 \mathrm{mg}$, $0.7 \mathrm{mmol}$ ). Single crystals suitable for $\mathrm{X}$-ray and $\mathrm{C}, \mathrm{H}, \mathrm{N}$ analysis were obtained by slow diffusion of $\mathrm{Et}_{2} \mathrm{O}$ into a solution of $\mathbf{8}-\mathbf{C u C l}_{2}$ in $\mathrm{CH}_{2} \mathrm{Cl}_{2}$ at room temperature. Yield: $275 \mathrm{mg}(99 \%)$ as a light-green solid; MS (FAB): $m / z(\%): 484(100)[M+\mathrm{H}]^{+}, 349(90)\left[M-\mathrm{CuCl}_{2}\right]^{+}, 188(50)$; IR $(\mathrm{KBr}): \tilde{v}=3430,2953,1745,1724,1461,1432,1383,1358,1291,1245$, $1215,1098,1018,993,975,815 \mathrm{~cm}^{-1}$; elemental analysis calcd (\%) for $\mathrm{C}_{14} \mathrm{H}_{24} \mathrm{O}_{8} \mathrm{~N}_{2} \mathrm{CuCl}_{2}$ (482.8): C 34.83, H 5.01, N 5.80; found: C 35.02, $\mathrm{H}$ $5.02, \mathrm{~N} 5.80$; UV/Vis $\left(\mathrm{CH}_{3} \mathrm{CN}\right): \lambda_{\max }(\varepsilon)=720(100), 390(1200), 291 \mathrm{~nm}$ (6200).

Crystal structure analysis data for $\mathbf{8}-\mathbf{Z n C l}_{\mathbf{2}}$ and $\mathbf{8}-\mathbf{C u C l}_{2}$ : $\mathrm{CCDC}-242592$ and CCDC-243021 contain the supplementary crystallographic data for this paper. These data can be obtained free of charge from The Cambridge Crystallographic Data Centre via www.ccdc.cam.ac.uk/data_request/cif.

Crystal structure analysis data for $\mathbf{8}-\mathbf{Z n C l}_{2}: \mathrm{C}_{14} \mathrm{H}_{24} \mathrm{Cl}_{2} \mathrm{~N}_{2} \mathrm{O}_{8} \mathrm{Zn} \cdot 2 \mathrm{CH}_{3} \mathrm{CN}$, $M_{\mathrm{r}}=566.73$; crystal dimensions $0.15 \times 0.15 \times 0.10 \mathrm{~mm}^{3}$; monoclinic space group $P 2(1) / n, a=11.4655(4), b=14.9823(5), c=15.2985(4) \AA$, $\beta=$ $101.728(2)^{\circ}, Z=4 ; F(000)=1176, \rho_{\text {calcd }}=1.463 \mathrm{Mg} \mathrm{m}^{-3}$; diffractometer: Nonius Kappa CCD area detector, $\mathrm{Mo}_{K \alpha}$ radiation $(\lambda=0.71073 \AA)$; $T=173(2) \mathrm{K}$; graphite monochromator; theta range: $2.03^{\circ}<\theta<27.48^{\circ}$; index range: $-14 \leq h \leq 14,-19 \leq k \leq 19,-19 \leq l \leq 19 ; 11380$ reflections measured, of which 5910 were independent and 4301 observed with $I>$ $2 \sigma(I)$; linear absorption coefficient $1.209 \mathrm{~mm}^{-1}$. The structure was solved by direct methods using SHELXS-97 and refined with all data (299 parameters) by full-matrix least-squares on $F^{2}$ using SHELXL-97;;74] all non-hydrogen atoms were refined anisotropically; $R 1=0.0595$ for $I>$ $2 \sigma(I)$ and $\mathrm{w} R 2=0.0955$ (all data); largest peak $=0.470 \mathrm{e}^{-3}$ and -0.368 e $\AA^{-3} \cdot{ }^{[74]}$ Extinction coefficient $0.0020(4)$.
Crystal structure analysis data for 8- $\mathrm{CuCl}_{2}: \mathrm{C}_{14} \mathrm{H}_{24} \mathrm{Cl}_{2} \mathrm{~N}_{2} \mathrm{O}_{8} \mathrm{Cu}, M_{\mathrm{r}}=$ 482.79; crystal dimensions $0.30 \times 0.10 \times 0.10 \mathrm{~mm}^{3}$; orthorhombic space group $P 2(1) 2(1) 2(1), a=7.0723(14), b=13.800(3), c=20.033$ (4) $\AA, Z$ $=4 ; F(000)=996, \rho_{\text {calcd }}=1.640 \mathrm{Mg} \mathrm{m}^{-3} ;$ diffractometer: Nonius KappaCCD area detector, $\mathrm{Mo}_{K \alpha}$ radiation $(\lambda=0.71073 \AA) ; T=173(2) \mathrm{K}$; graphite monochromator; theta range: $2.51^{\circ}<\theta<27.49^{\circ}$; index range: $-9 \leq h \leq 9,-17 \leq k \leq 17,-25 \leq l \leq 25 ; 4438$ reflections measured, of which 4438 were independent and 3735 observed with $I>2 \sigma(I)$; linear absorption coefficient $1.434 \mathrm{~mm}^{-1}$. The structure was solved by direct methods using SHELXS-97 and refined with all data (244 parameters) by fullmatrix least-squares on $F^{2}$ using SHELXL-97; ${ }^{[74]}$ all non-hydrogen atoms were refined anisotropically; $R 1=0.0476$ for $I>2 \sigma(I)$ and $\mathrm{w} R 2=$ 0.0833 (all data); largest peak $=0.308 \mathrm{e} \AA^{-3}$ and $-0.400 \mathrm{e} \AA^{-3} \cdot{ }^{[74]}$ Absolute structure parameter $-0.018(12)$.

\section{Acknowledgements}

We thank the SFB 583, Redoxaktive Metallkomplexe - Reaktivitätssteuerung durch molekulare Architekturen for financial support, and Dr. R. Waibel of the Institut für Pharmazie der Universität Erlangen-Nürnberg for his help during the measurements of the $\mathrm{CD}$ spectra.

[1] C. M. Dobson, Nature 2003, 426, 884-890.

[2] A. Fersht, Structure and Mechanism in Protein Science: A Guide to Enzyme Catalysis and Folding, Freeman, New York, 1999.

[3] D. J. Selkoe, Nature 2003, 426, 900-904.

[4] N. Voyer, The Development of Peptide Nanostructures, Vol. 184, Springer Berlin, Heidelberg, 1996.

[5] M. Fischer, F. Vögtle, Angew. Chem. 1999, 111, 934-955; Angew. Chem. Int. Ed. 1999, 38, 884-905.

[6] J. M. Fréchet, D. A. Tomalia, Dendrimers and other Dendritic Polymers, Wiley, New York, 2001.

[7] W. A. Goddard, A. M. Naylor, D. A. Tomalia, Angew. Chem. 1990, 102, 119-157; Angew. Chem. Int. Ed. Engl. 1990, 29, 138-175.

[8] S. M. Grayson, J. M. J. Fréchet, Chem. Rev. 2001, 101, 3819-3868.

[9] G. R. Newkome, C. Moorefield, F. Vögtle, Dendrimers and Dendrons: Concepts, Syntheses, Perspectives, Wiley-VCH, Weinheim, 2001.

[10] J. C. Smith, C. B. Gorman, Acc. Chem. Res. 2001, 34, 60-71.

[11] F. Vögtle, J. F. Stoddart, M. Shibasaki, Stimulating Concepts in Organic Chemistry, Wiley-VCH, New York, 2000.

[12] S. Hecht, J. M. J. Fréchet, Angew. Chem. 2001, 113, 76-94; Angew. Chem. Int. Ed. 2001, 40, 74-91.

[13] D. K. Smith, F. Diederich, Chem. Eur. J. 1998, 4, 1353-1361.

[14] A. W. Bosman, H. M. Janssen, E. W. Meijer, Chem. Rev. 1999, 99, $1665-1688$.

[15] M. Ballauff, C. N. Likos, Angew. Chem. 2004, 116, 3060-3082; Angew. Chem. Int. Ed. 2004, 43, 2998-3020.

[16] I. O. Götze, C. N. Likos, Macromolecules 2003, 36, 8189-8197.

[17] R. L. Lescanec, M. Muthukumar, Macromolecules 1990, 23, $2280-$ 2288.

[18] M. L. Mansfield, L. I. Klushin, Macromolecules 1993, 26, 4262-4268.

[19] M. Murat, G. S. Grest, Macromolecules 1996, 29, 1278-1285.

[20] M. Rubinstein, D. Boris, Macromolecules 1996, 29, 7251-7260.

[21] M. R. Rauckhorts, P. J. Wilson, S. A. Hatcher, C. M. Hadad, J. R. Parquette, Tetrahedron 2003, 59, 3917-3923.

[22] J. Recker, J. Tomick, J. R. Parquette, J. Am. Chem. Soc. 2000, 122, $10298-10307$

[23] B. Huang, M. A. Prantil, T. L. Gustafson, J. R. Parquette, J. Am. Chem. Soc. 2003, 125, 14518-14530.

[24] H. F. Chow, T. K. K. Mong, M. F. Nongrum, C. W. Wan, Tetrahedron 1998, 54, 8543-8660.

[25] H. W. I. Peerlings, E. W. Meijer, Chem. Eur. J. 1997, 3, 1563-1570.

[26] D. Seebach, P. B. Rheiner, G. Greiveldinger, T. Butz, H. Sellner, Top. Curr. Chem. 1998, 197, 127-164.

[27] C. W. Thomas, Y. Tor, Chirality 1998, 10, 53-59. 
[28] R. Balasubramanian, P. Rao, U. Maitra, Chem. Commun. 1999, 23, 2353-2355.

[29] H.-T. Chang, C.-T. Chen, T. Kondo, G. Siuzdak, K. B. Sharpless, Angew. Chem. 1996, 108, 202-206; Angew. Chem. Int. Ed. Engl. 1996, 35, 182-186.

[30] J.-L. Chaumette, M. J. Laufersweiler, J. R. Parquette, J. Org. Chem. 1998, 63, 9399-9405.

[31] S. Cicchi, A. Goti, C. Rosini, A. Brandi, Eur. J. Org. Chem. 1998, $2591-2597$.

[32] J. Issberner, M. Bohme, S. Grimme, M. Nieger, W. Paulus, F. Vögtle, Tetrahedron: Asymmetry 1996, 7, 2223-2232.

[33] D. M. Junge, D. V. McGrath, Tetrahedron Lett. 1998, 39, 1701.

[34] J. Kress, A. Rosner, A. Hirsch, Chem. Eur. J. 2000, 6, 247-257.

[35] C. C. Mak, H. F. J. Chow, Chem. Commun. 1996, 1185.

[36] C. C. Mak, H. F. J. Chow, J. Chem. Soc. Perkin Trans. 1 1997, 91-97.

[37] C. C. Mak, H. F. J. Chow, Pure Appl. Chem. 1997, 69, 483-489.

[38] J. R. McElhanon, D. V. McGrath, J. Am. Chem. Soc. 1998, 120, $1647-1656$

[39] J. R. McElhanon, D. V. McGrath, J. Org. Chem. 2000, 65, 35253529.

[40] P. Murer, D. Seebach, Angew. Chem. 1995, 107, 2297-2300; Angew. Chem. Int. Ed. Engl. 1995, 34, 2116-2119.

[41] P. Murer, D. Seebach, Helv. Chim. Acta 1998, 81, 603-631.

[42] G. R. Newkome, X. Lin, C. D. Weis, Tetrahedron: Asymmetry 1991, 2, 957-960.

[43] B. Buschhaus, W. Bauer, A. Hirsch, Tetrahedron 2003, 59, 38993915.

[44] M. Schemjakin, Angew. Chem. 1960, 72, 342.

[45] C. Gorman, J. C. Smith, Adv. Mater. 1998, 10, 295-309.

[46] C. Gorman, J. C. Smith, Acc. Chem. Res. 2001, 34, 60-71.

[47] H. J. Van Manen, F. C. J. M. van Veggel, D. N. Reinhoudt, Top. Curr. Chem. 2001, 217, 121-162.

[48] M. Venturi, S. Serroni, A. Juris, S. Campagna, V. Balzani, in Topics in Current Chemistry: Dendrimers, Vol. 197 (Ed.: F. Vögtle), Springer, Berlin, Heidelberg, 1998, pp. 193-228.

[49] M. Enomoto, T. Aida, J. Am. Chem. Soc. 1999, 121, 874-875.

[50] M. Enomoto, T. Aida, J. Am. Chem. Soc. 2002, 124, 6099-6108.

[51] C. Saudan, V. Balzani, M. Gorka, S. K. Lee, J. Van Heyst, M. Maestri, P. Ceroni, V. Vicinelli, F. Vögtle, Chem. Eur. J. 2004, 10, $899-$ 905.

[52] T. L. Chasse, R. Sachdeva, Q. Li, Z. Li, R. J. Petrie, C. B. Gorman, J. Am. Chem. Soc. 2003, 125, 8250-8254.
[53] C. Gorman, C. R. Acad. Sci. Ser. IIc C. R. Chimie 2003, 6, 911-918.

[54] V. L. Beyer, G. Kuhn, E. Hoyer, Z. Anorg. Chem. 1965, 339, 8-19.

[55] K. B. Nolan, M. Shuaib, Transition Met. Chem. 1980, 5, 230-231.

[56] G. Höfle, W. Steglich, Synthesis 1972, 619-621.

[57] B. Neiss, W. Steglich, Angew. Chem. 1978, 90, 556-557; Angew. Chem. Int. Ed. Engl. 1978, 17, 522-524.

[58] A. Bodansky, M. Bodansky, The Practice of Peptide Synthesis, 2nd ed., Springer, Berlin, 1994.

[59] J. F. W. Keana, J. S. Mann, J. Org. Chem. 1990, 55, 2869-2871.

[60] A. Zelewsky, U. Knof, Angew. Chem. 1999, 111, 312-333; Angew. Chem. Int. Ed. 1999, 38, 302-322.

[61] R. Kuroda, Y. Saito, Circular Dichroism, 2nd ed., Wiley-VCH, New York, 2000.

[62] J. K. Beattle, Acc. Chem. Res. 1971, 4, 253-259.

[63] Turbomole (Version 5.6): R. Ahlrichs, M. Bär, H.-P. Baron, R. Bauernschmitt, S. Böcker, M. Ehrig, K. Eichkorn, S. Elliott, F. Furche, F. Haase, M. Häser, H. Horn, C. Huber, U. Huniar, M. Kattannek, C. Kölmel, M. Kollwitz, K. May, C. Ochsenfeld, H. Öhm, A. Schäfer, U. Schneider, O. Treutler, M. von Arnim, F. Weigend, P. Weis, H. Weiss, Universität Karlsruhe, 2004.

[64] A. D. Becke, Phys. Rev. A 1988, 38, 3098-3100.

[65] J. P. Perdew, Phys. Rev. B. 1986, 33, 8822-8824.

[66] A. Schäfer, H. Horn, R. Ahlrichs, J. Chem. Phys. 1992, 97, $2571-$ 2577.

[67] K. Eichkorn, O. Treutler, H. Öhm, M. Häser, R. Ahlrichs, Chem Phys. Lett. 1995, 240, 283-289.

[68] R. Bauernschmitt, R. Ahlrichs, Chem. Phys. Lett. 1996, 256, 454464.

[69] C. Diedrich, S. Grimme, J. Phys. Chem. A. 2003, 107, 2524-2539.

[70] S. Grimme, Rev. Comput. Chem. 2004, 20, 153.

[71] A. D. Becke, J. Chem. Phys. 1993, 98, 5648-5652.

[72] P. J. Stevens, F. J. Devlin, C. F. Chablowski, M. J. Frisch, J. Phys. Chem. 1994, 98, 11623-11627.

[73] C. Diedrich, S. Grimme, J. Phys. Chem. A 2003, 107, 2524-2539.

[74] SHELXS-97 and SHELXL-97, programs for crystal structure solution and structure refinement, G. M. Sheldrick, Universität Göttingen, 1997.

[75] ORTEP-3 for Windows 1.06: L. J. Farrugia, J. Appl. Crystallogr. 1997, 30, 565 .

Received: December 23, 2004 Published online: April 5, 2005 